\section{2) Practical Reasons: The Problem of Gridlock}

\author{
Ruth Chang
}

Philosophical ethics in the last century was occupied by two main lines of investigation: ethical theorizing - clarifications of and refinements to theories of morally right action, primarily consequentialism, deontology, and virtue ethics - and, meta-ethics - the application of ideas from metaphysics, epistemology, and the philosophy of language to the nature of moral thought and discourse. In this century, at least so far, much of the most exciting work in philosophical ethics turns away from these mainstays and focuses on a more general and deeper set of issues that straddle and go beyond ethical theory and meta-ethics, what we might call the philosophy of practical reason.

The philosophy of practical reason ranges over a number of issues but its most central concern the nature of normative practical reasons-the considerations that support or count in favor of performing some action or having some attitude. Normative practical reasons include moral reasons but many more besides. They are arguably the most basic building blocks of theorizing in any normative domain and the most basic subject matter of meta-normative theorizing. ${ }^{1}$

The chapter has two aims. The first is to propose a general framework for organizing some central questions about normative practical reasons in a way that separates importantly distinct issues that are easily run together. Setting out this framework provides a snapshot of the leading types of view about practical reasons as well as a deeper understanding of what are widely regarded to be some of their most serious difficulties.

The second aim is to use the proposed framework to uncover and diagnose is a structural problem that plagues the debate about practical reasons. A striking feature of this debate is that it has been marked by the persistence of three dominant types of view. The problem is not that the same types of view persist - that, alas, might be a feature of the philosophical condition-but why these particular types do. As I will suggest, these types persist because they make substantive assumptions in answer to one question of the framework, which in turn have profound effects on how arguments for and against one type of view relate to arguments for and against another type. In short, arguments favoring one type of view have merit largely only given that substantive assumption, while arguments against it have force largely only given a different substantive assumption. As a result, a common move in the debate involves a proponent of one type of view offering what she and others proposing that type consider to be a devastating criticism of an opposing type of view, only to find that her criticism is shrugged off by her opponents as easy to answer, misguided, or having little significance for their view. ${ }^{2}$ This isn't, I will suggest, due to conceptual blindness or mere slavish devotion to a theory but something fundamental about the argumentative structure of a debate over genuinely shared issues. Hence, the debate about practical reasons suffers from argumentative gridlock. The proposed framework helps us to see why this is so, and, as I will tentatively suggest at the end of the paper, what we might do to move beyond it.

\section{A Framework}

1.1 Three Questions about Normative Practical Reasons Debate about practical reasons might be usefully organized around three meta-normative questions:

(a) What is the "content" of normative practical reasons?

(b) What is the nature of their normative force?

(c) What is the source of this normative force?

These questions are "meta-normative" in that they are, on their face, metaphysical questions about the general nature of practical reasons and not substantive, normative questions about what reasons we have or the substantive conditions under which, by the lights of a normative theory, we have them. ${ }^{3}$ As we will see, these three questions provide a concrete set of issues by which we can gain both a synoptic view of the leading theories about practical reasons and a deeper understanding of what might be regarded as their main difficulties.

First. Which sorts of considerations-let's assume that they are facts-are normative practical reasons? On the face of it, a wide variety of facts can be a normative reason for you to do something - that you promised to, that you want to, that doing it would be good in some way, and so on. But perhaps these facts can be systematized so that some are derivative while others not, with all the nonderivative reasons being of a single unified sort. Is there a single type of fact that systematically carries the action-guidingness of a reason? 


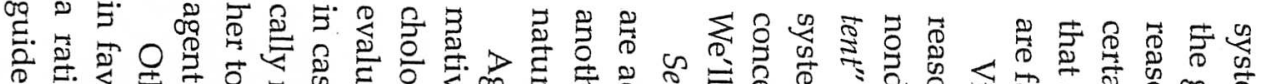

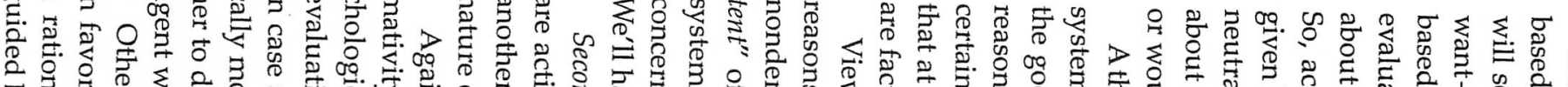

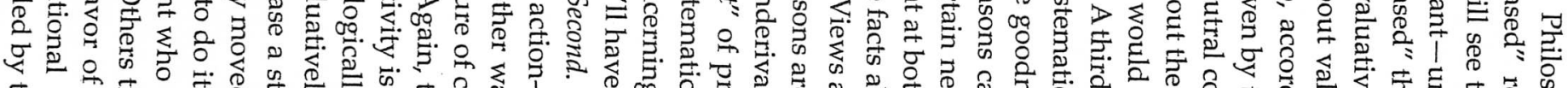

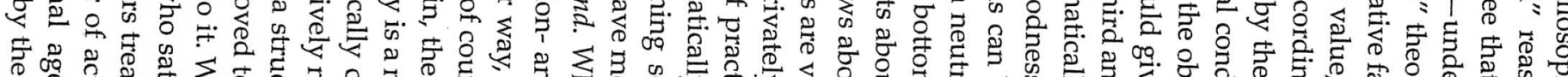

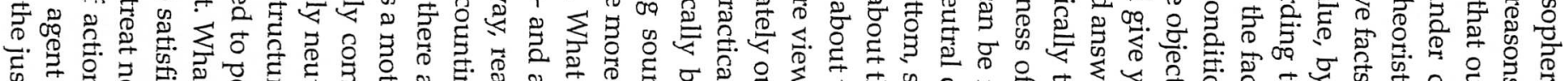

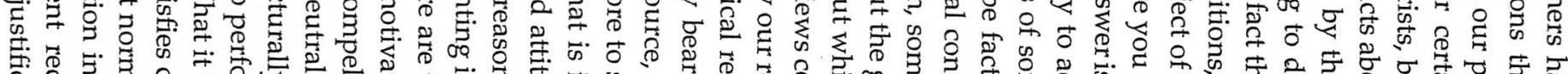

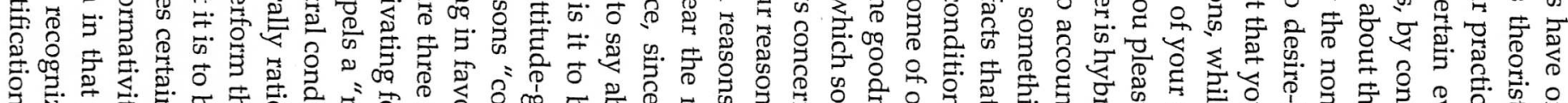

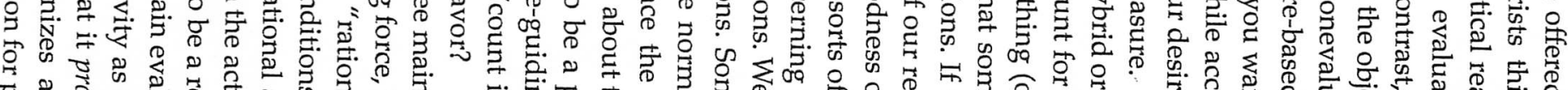

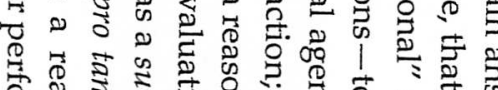
कृ క. की एक

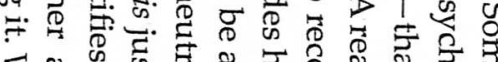
¿क फ़्स

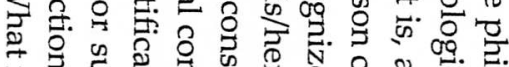

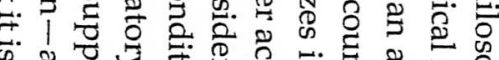

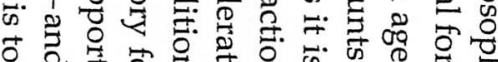
० ס

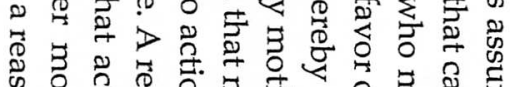

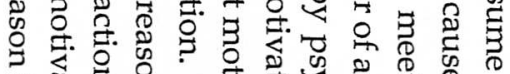

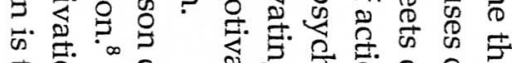

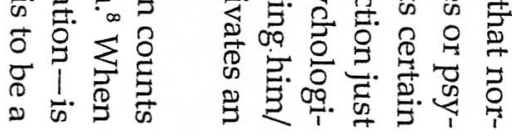

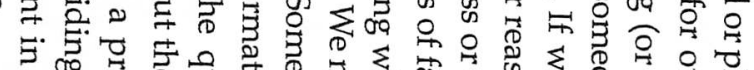
क्व

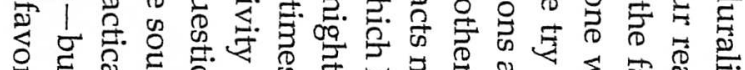

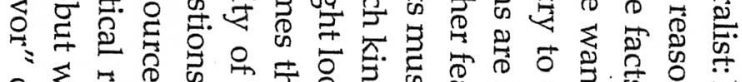
뉴유

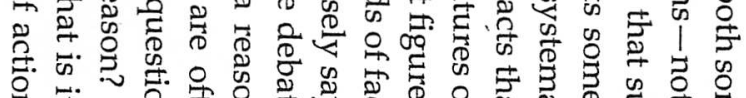

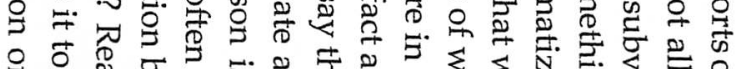
○

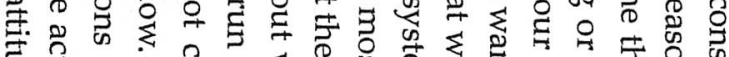

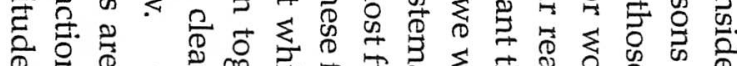

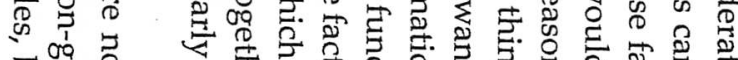

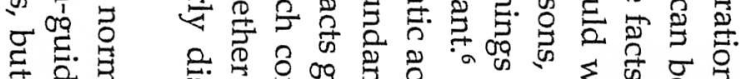
局 क्ष

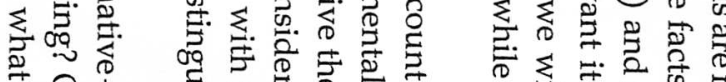

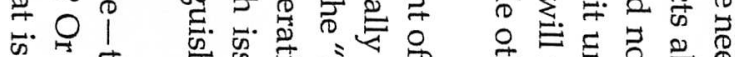

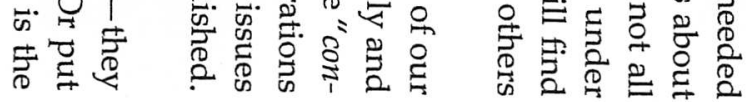

苗

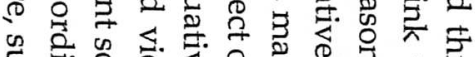

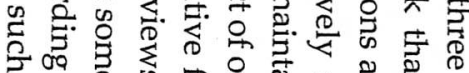
क 0 ए

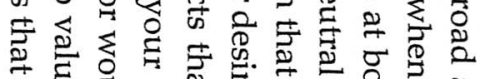

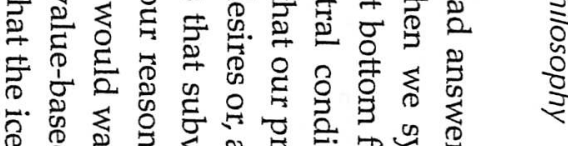

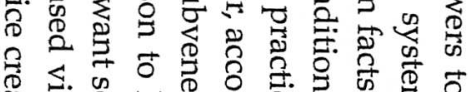
क ज 0 ठ ऊ. ค స 矢

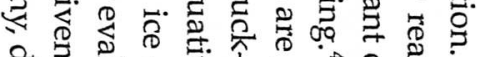

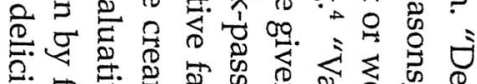

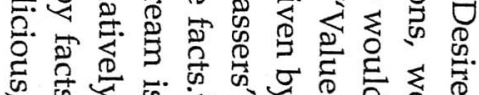

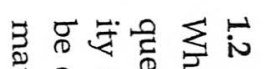

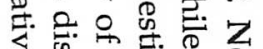

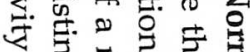
0 o

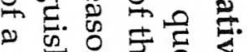

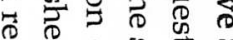

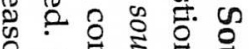

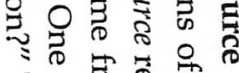
ㅂ. ㅎ. 율

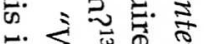
का क्ष

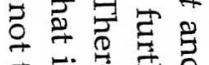

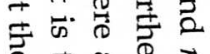

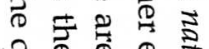
유 ते त्र

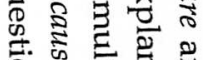
‥ कृ 유ㅁㅠㅠ

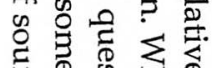

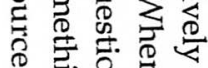
ज० की की इक क के है

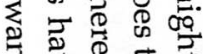
鸟. 索常 की 次焉 ธ节营念

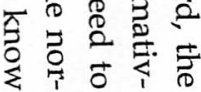

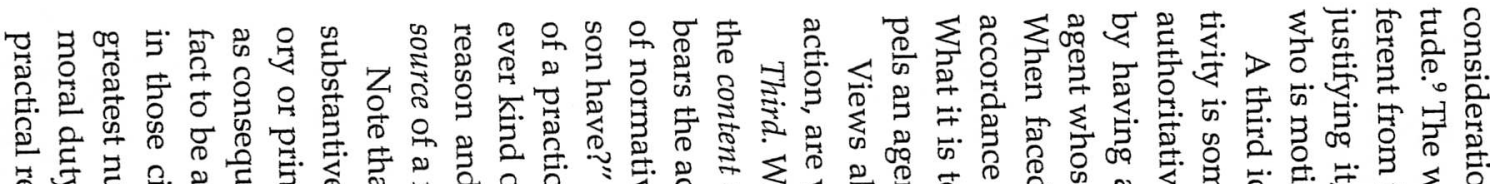

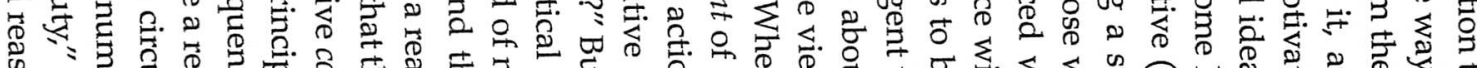

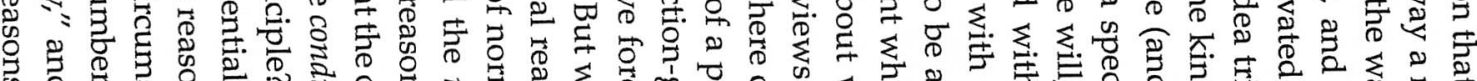

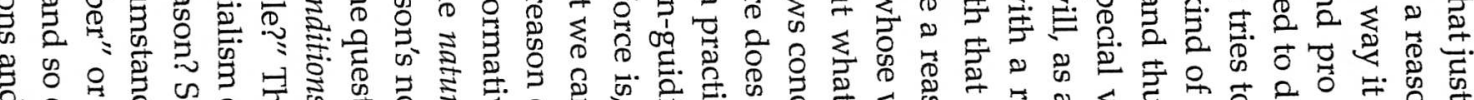

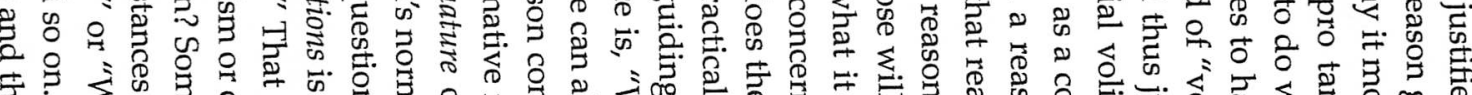

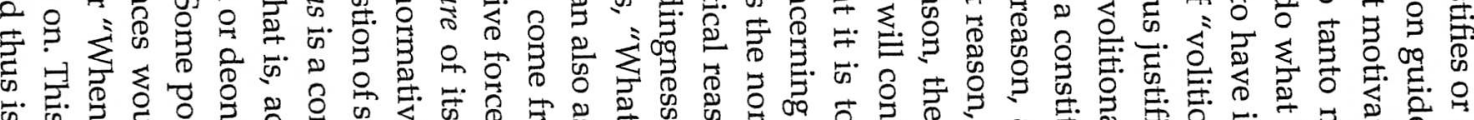
क क.

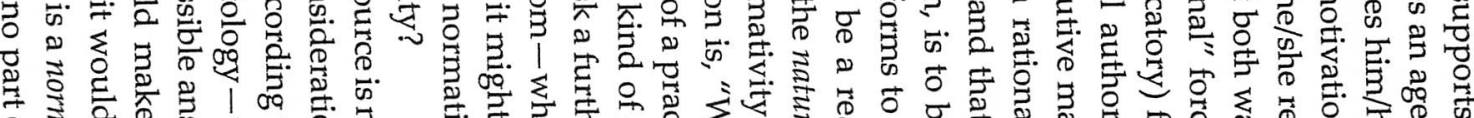

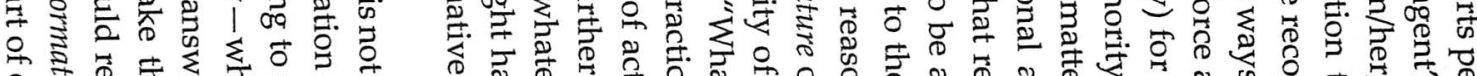

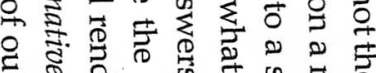
ह ऽ

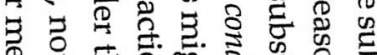
क

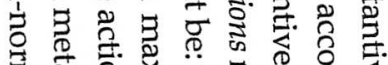

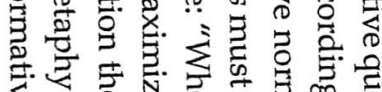

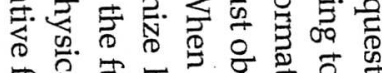

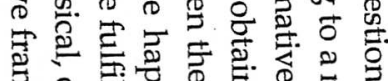

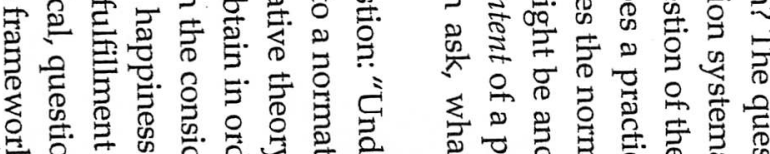

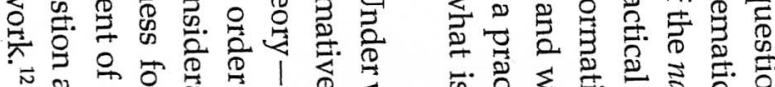

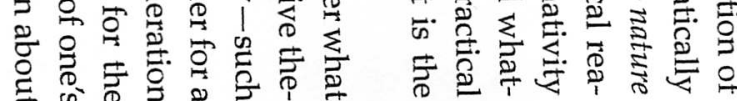

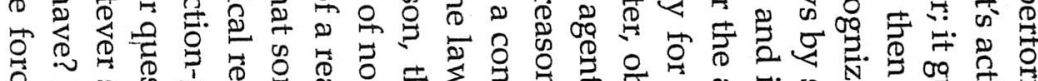

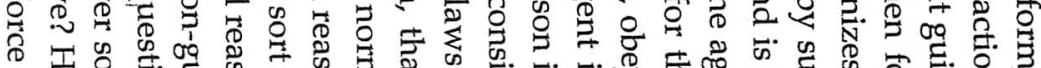

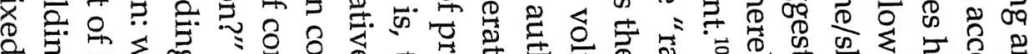

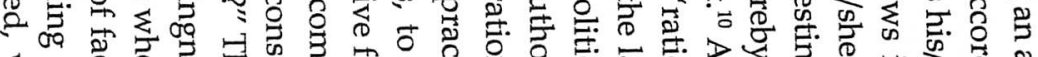

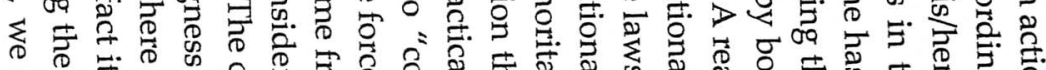

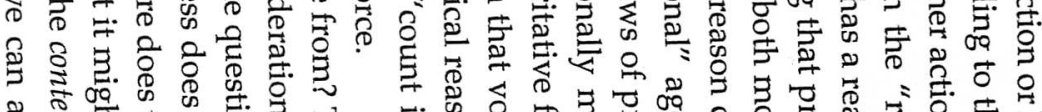

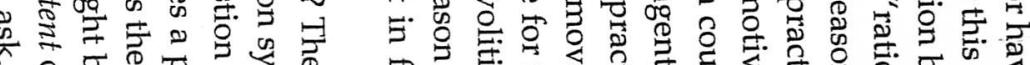

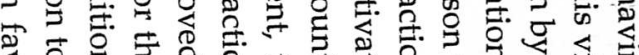

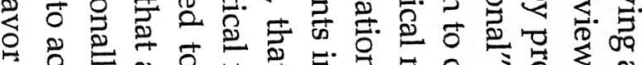

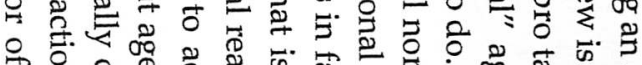

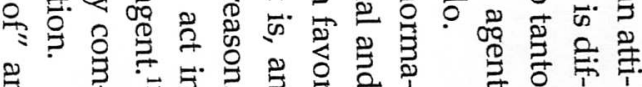

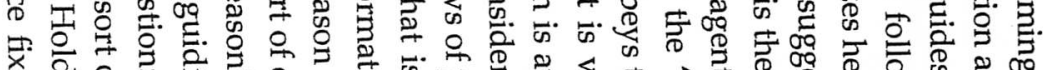


the source of normativity, we don't mean to ask what causes something to be normative, if indeed that question makes sense. Instead, we are looking for something deeper-roughly, what metaphysically determines something's being a reason.

Another question, somewhat closer to what we have in mind, asks what is the modally subvening base of something's being a reason, that is, which facts modally covary with the fact that something has the action-guidingness of a reason. The source of normativity, however, isn't what modally covaries with something's being a reason - it isn't the fact, for instance, that must change when there is a change in the fact that something is a reason. Consider an analogy. Suppose God is the source of morality; God - or a supernatural realm-is where morality comes from. This view about source is consistent with the idea that moral facts supervene on natural facts, that you can't have a change in the moral facts without having a change in the natural facts. So the sense of "source" being sought here is not that of a modally subvening base.

A third question asks what general principle or law subsumes the fact that something is a reason. There is a sense in which the normativity of specific reasons may "come from" more general normative reasons or principles, if the most extreme forms of particularism are false. A specific reason may be an instance or instantiation of a general principle such that when it holds, it explains why a general principle holds. But when we wonder about the source of normativity, our question is not about the subsumption of particular reasons under general normative reasons but rather about one thing being the metaphysical fount of another. When we ask for the source of normativity by asking "Where does the normativity of a reason come from?" we are looking for an explanatory connection that holds of metaphysical necessity but is neither cause, supervenience, nor subsumption.

Intuitively when we ask about the source of normativity, we are asking what "makes" a fact normative, what it is "in virtue of which" some fact has the normativity of a practical reason. If we trace the normativity of a reason back to its fount, we will reach what "makes" the consideration a reason in the first place-its normative source. As metaphysicians might say, we are looking for the metaphysical ground of something's being a reason. ${ }^{14}$ There is burgeoning literature on "ground" we needn't engage; for our purposes, we can work with the basic idea that $x$ grounds $y$ when $x$ gives a metaphysically necessary explanation of $y$ that is not causal, modal covariation, or subsumption.

Now there is more than one way in which one fact can make something the case, different ways in which a fact can be grounded. The most natural way one fact can ground another is by constituting it. The fact that $p$ or the fact that $q$ ground the fact that $\mathrm{p}$ or $\mathrm{q}$ in that the former facts constitute the latter fact. The fact that it's $\mathrm{H}_{2} \mathrm{O}$ grounds the fact that it's water in that being $\mathrm{H}_{2} \mathrm{O}$ constitutes being water. Or consider causation. Striking a match causes it to light. What "makes" the striking cause the lighting, that is, what constitutes the fact that the striking causes the lighting? One answer might be "a nomological law according to which under conditions $C$, a striking of a match causes the match to light," and another might be "a set of regularities whereby a striking of a match under conditions $C$ is followed by its being lit." This law, or this regularity, is what constitutes the fact that the striking causes the lighting. It is where the causality of the striking comes from. Tracing the causality back to its fount by discovering what constitutes something's having it, we end at the law or regularity.

So one way to answer the question, What is the source of $x$ ? is by saying what constitutes the fact that $x$. And thus one way of answering the source question about normativity is by saying what constitutes the fact that something is a reason.

Another way something can-perhaps degenerately-be grounded is by being "self-grounded," that is, by being its own fount. God may be causa sui, the cause or ground of himself. Or consider, again, the case of cause. If we ask, "Where does a law that constitutes the fact that one event causes another come from?," the answer may be "Nowhere" or, for our purposes, what we can take to be its equivalent, "From itself." The law is a nomological necessity. All necessary truths are self-grounded; there is nothing further that explains them. Contingent brute facts can also be self-grounded. Suppose we ask, "Where does the negative charge of an electron come from?" The answer might be "From the fact that an electron has a negative charge"; there's no more explanation to be had, end of story. Facts that are explanatorily primitive are selfgrounded; they cannot be accounted for in any other terms-they represent the end of the line in explanation-and hence are their own ground.

So another way to answer the source question is by appealing to the fact whose source we are seeking in the first place-the fact is its own source. If we ask where the normativity of a reason comes from, one possible answer is that there is nothing further that explains why a fact has the normativity of a reason other than the fact that it has the normativity of a reason. The fact that something is a reason might be its own normative source.

I believe there is a third way in which one fact can intuitively "make" or "ground" another that is neither a case of constitution nor one of self-grounding. This is a relation of metaphysical creation. Consider, again, the case of cause. The fact that the striking of the match causes the lighting may be constituted by nomological laws, but what is the source of those nomological laws? Where do they come from? We might answer the source question by appealing to God who makes those laws. God is the source of the nomological laws in that he metaphysically creates them, where creation is a kind of metaphysical determination beyond causation or constitution. (More needs to be said about this relation which cannot be said here).$^{15}$ So a final possible way to answer the question, "What is the source of $x$ ?" is to say what metaphysically creates $x$-whatever that turns out to be. 


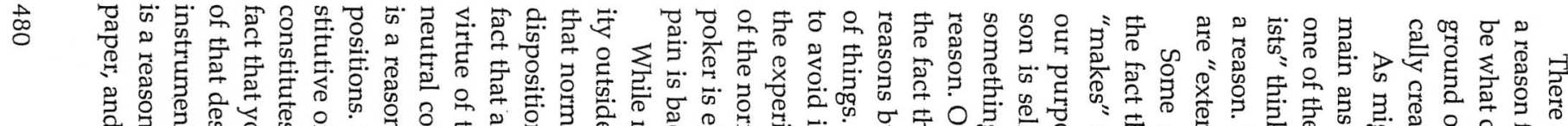

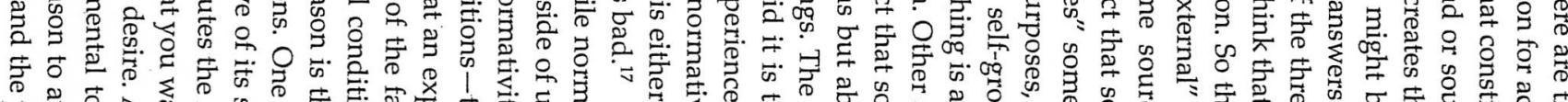

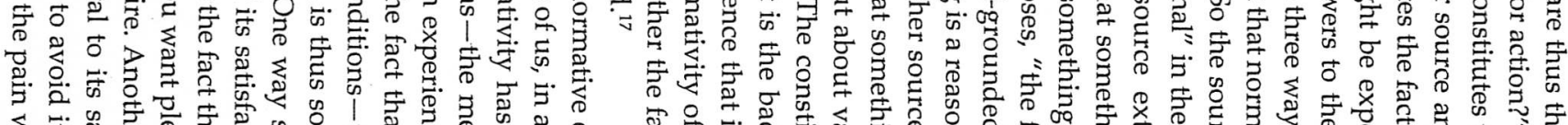

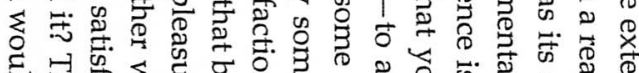

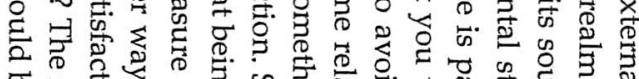

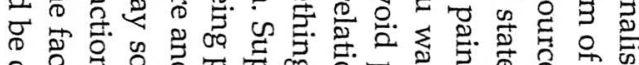

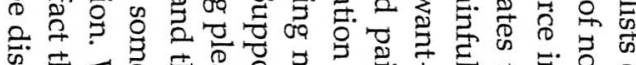

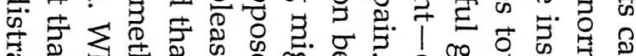

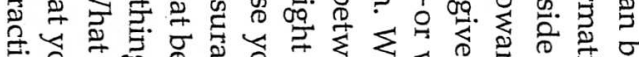

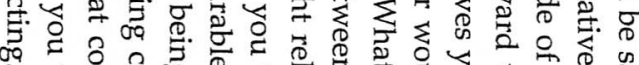

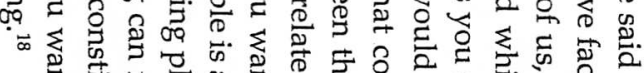

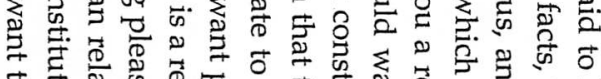
ठ

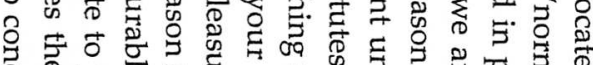
ते

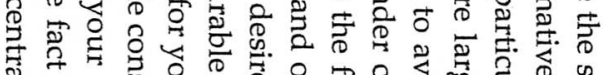

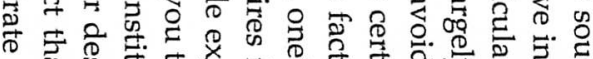

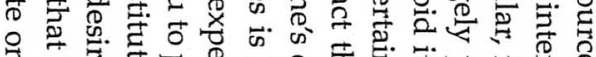

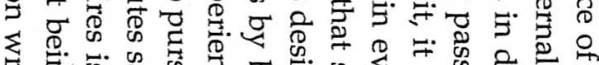

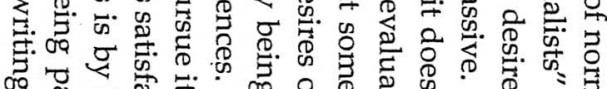

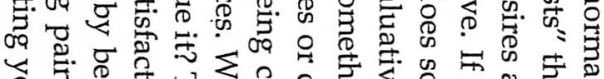

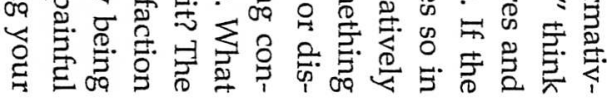

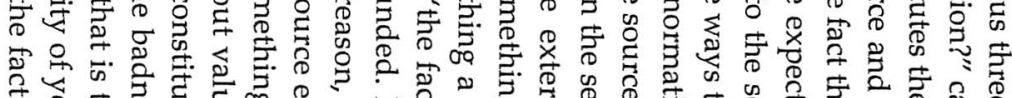

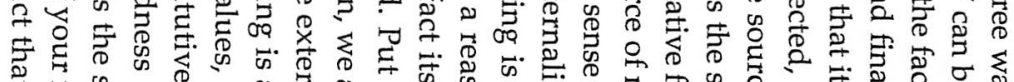

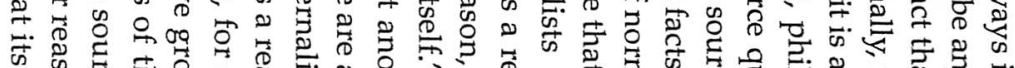

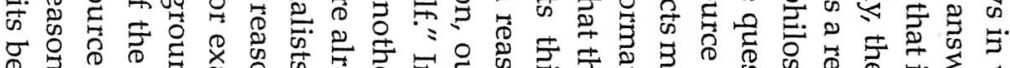

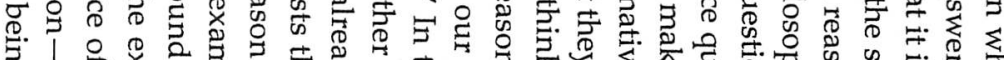

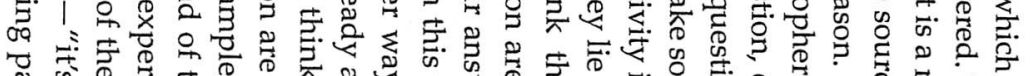
के के

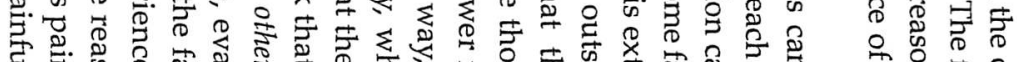

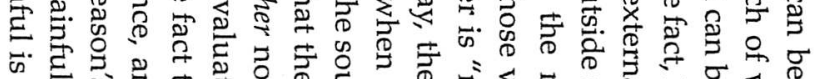

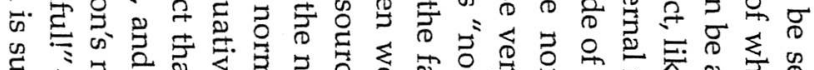
है।

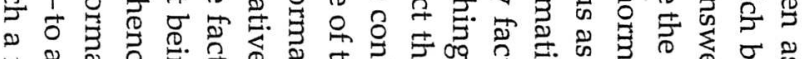

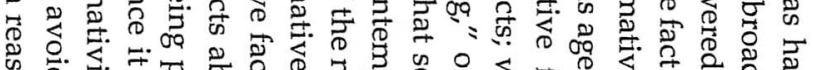

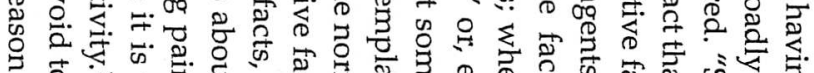

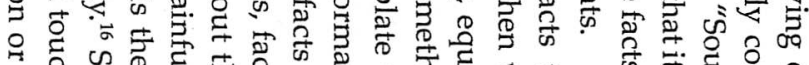

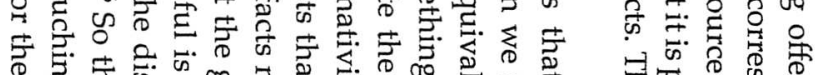

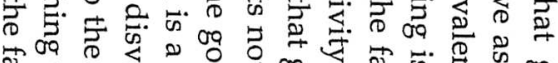

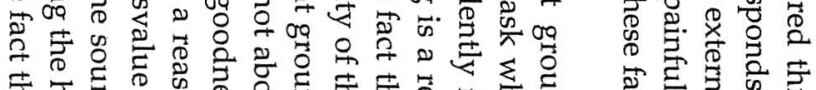

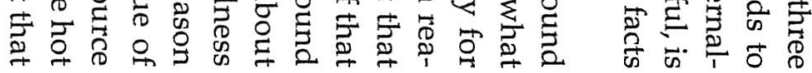

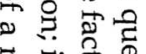
둥 象产 응 = 5 of 品营 $\sum$ क 焉空

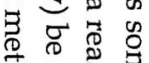

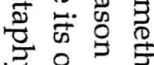
究.

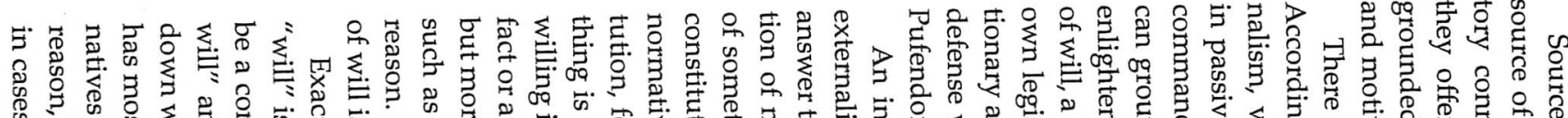
क

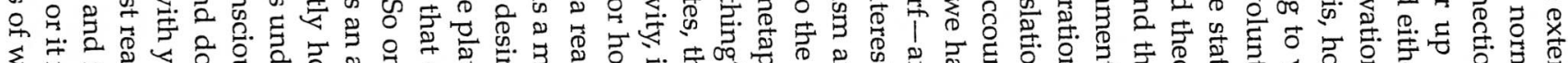

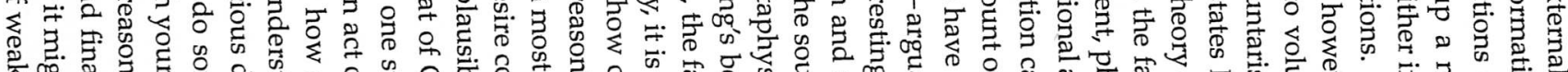

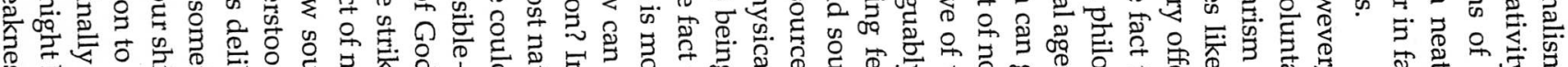

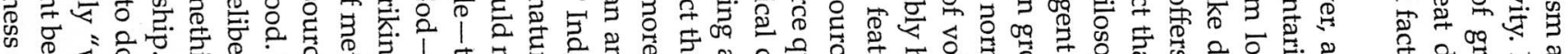

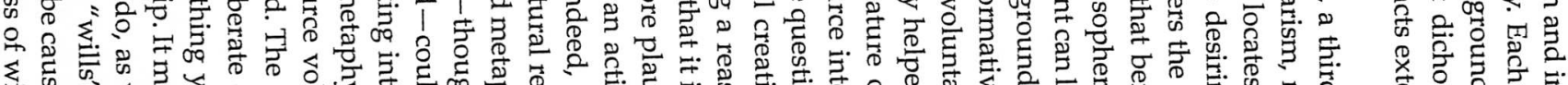

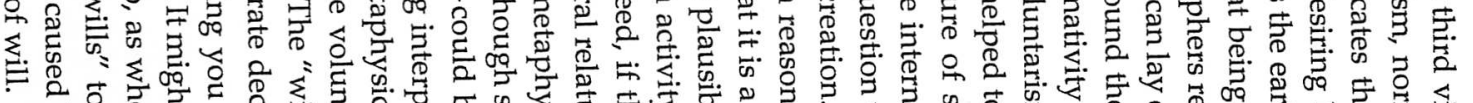

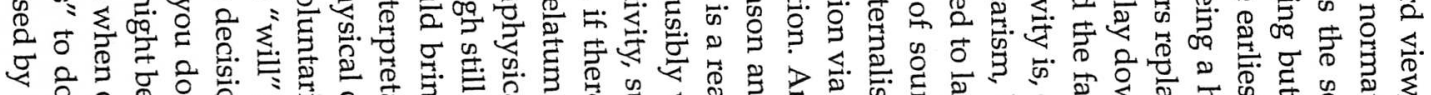

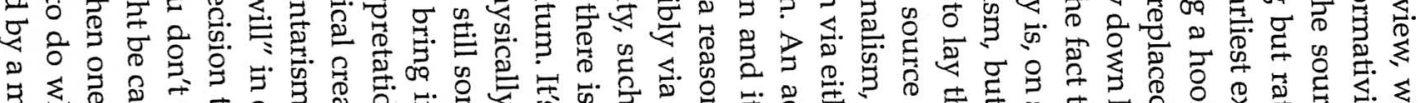

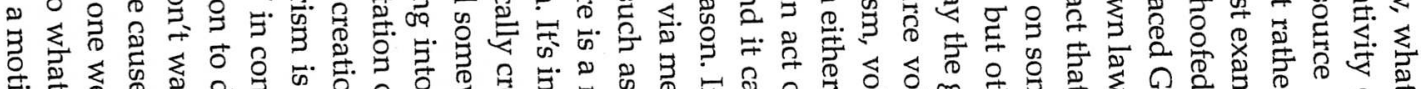

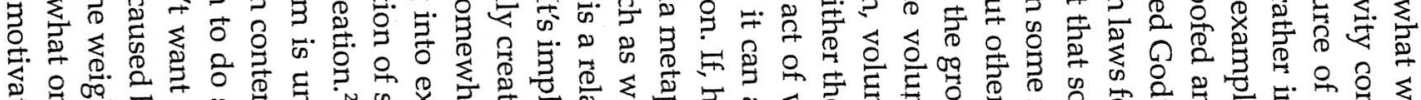

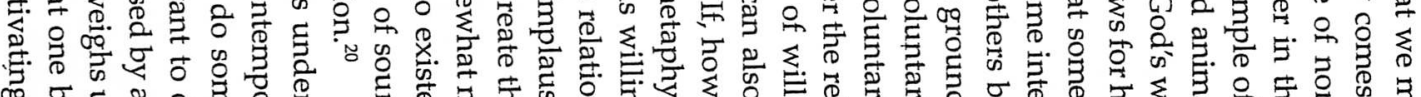

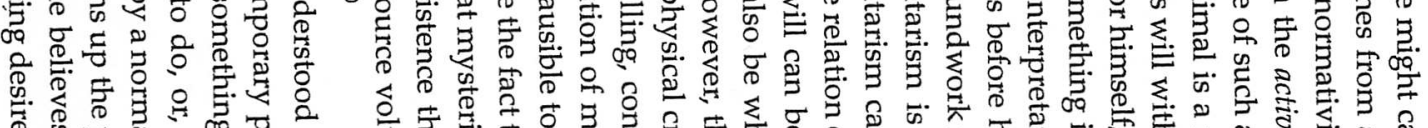

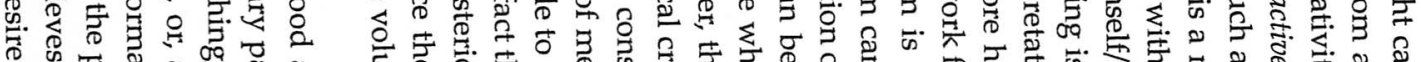
क क.

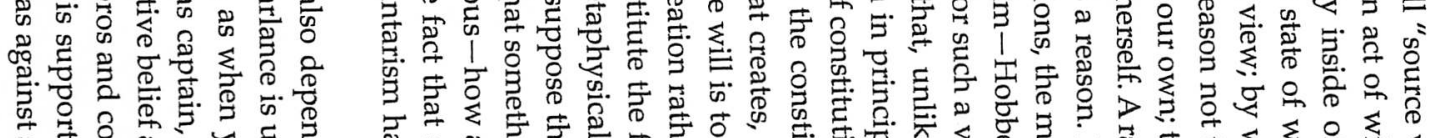

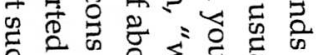

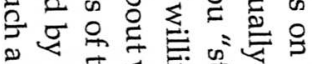

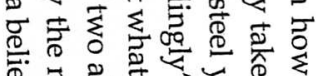

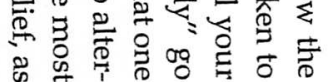

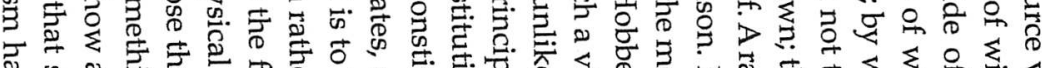

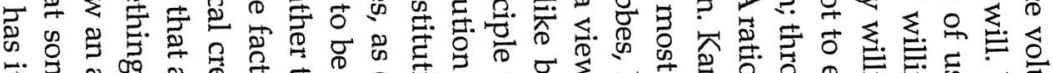

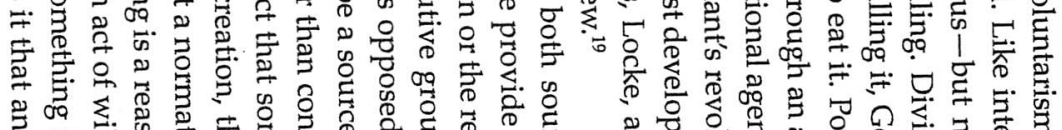

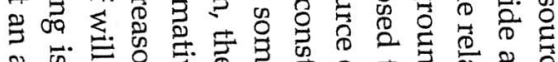

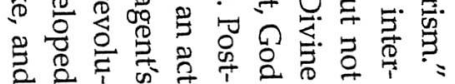

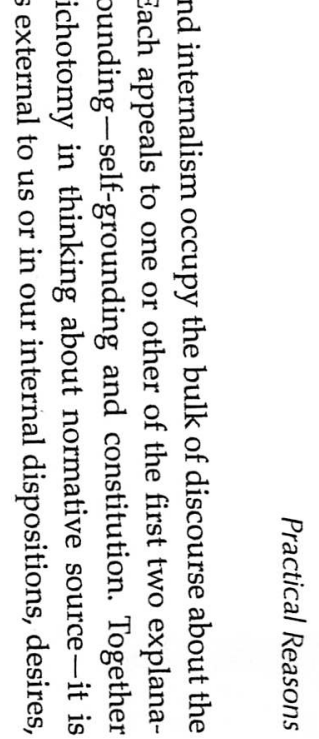


But the "will" is also sometimes taken to represent the agent himself/herself and "willing" correspondingly taken to be an activity constitutive of agency. You might consciously and deliberately decide to exercise every day, but your will-your agency -is not cooperating. Willing is thus sometimes understood not as a conscious, deliberate decision to do something but as the activity of (rational) agency as such. Perhaps the rational will in this sense-rational agency itself-is what constitutively grounds the fact that something is a reason: a will constrained by rationality is that in virtue of which something is a reason. That was Kant's view, at least by the lights of some modern interpreters. ${ }^{21}$ Or we might understand willing as the activity of agency involved in putting yourself-your agency-behind something. Perhaps by willing that something is a reason - putting your agency behind it as a reason-you can create or construct it as a reason in something like the way God's willing "Let there be light" creates or constructs the fact that there is light. ${ }^{22}$ Voluntarists views, while the most intriguing, are among the most mysterious and least understood.

\subsection{The Three Questions are Distinct}

One common mistake is to move from a view about the content of one's reasons to a conclusion about the nature of their normativity. So, for example, it might be thought that if reasons are desires then it follows that normativity is a motivating force, for how else can your desire for something be action-guiding except by motivating you to action? Such a view overlooks the logical independence of which considerations are action-guiding from actionguidingness itself. Your desire - or the fact that you want something - can be your reason, but it can be action-guiding by justifying your action, not simply by motivating it. Perhaps wanting the ice cream is normative because it justifies getting some.

Nor would it be correct to move from a view about the content of one's reasons to the source of their normativity. Some philosophers seem to assume that because reasons are evaluative facts or the facts that subvene them, what grounds the fact that they are reasons must itself be a normative fact. But this assumption must be defended against alternative possibilities. Even if the content of my reason is the fact that doing something would be good or pleasant, such a fact might be normative in virtue of a relation between doing that thing and my desires or dispositions. What makes a fact normative is one thing while the content of that fact is another. ${ }^{23}$

It would also be a mistake to move from a view about the source of normativity to a view about the nature of normative force. ${ }^{24}$ Suppose, for example, that the source of normativity is one's desires. It would be a mistake to conclude that normativity is thereby a motivational force since it could be that being properly related to one's desires could be that in virtue of which one's action is justified. Satisfying what you would most want under certain constraints could be what makes your action have the justificatory force of a reason.

The same goes for sliding from source to content. Just because, say, the source of normativity is a realm of irreducibly normative facts, it does not follow that one's reasons are irreducibly normative facts. Perhaps it is an irreducibly normative fact that wanting to do something under certain constraints is, systematically, a reason to do it. Nor does it follow that if desires are what make something a reason, that one's reasons just are the fact that one wants something. The fact that is one's reason should be kept distinct from the fact that this fact is one's reason. ${ }^{25}$

Finally, views about the nature of normative force are logically independent of views about content or source. It might be thought that reasons must be desires if normativity is a matter of motivation, for what could motivate but desires? But if normativity is a motivating force, it does not follow that reasons are desires, since, as Nagel taught us long ago, desires can themselves be "motivated" by normative beliefs. My belief that cleaning up the mess is good can cause or otherwise necessitate me, as a rational agent, to be motivated to clean it up. My reason is that cleaning up the mess is good, and the normativity it carries could be the motivational force of the desire to clean up the mess that recognition of the goodness of doing so necessitates in a rational being. Of course it is a further substantive question as to whether being rational requires having certain dispositions or desires, such as the desire to do what one believes one has a reason to do, but the point here is that understanding normativity as motivation does not require one to conclude that desires are reasons. Nor does it follow that if normativity is a matter of motivational force that this force must have its source in one's desires or dispositions. It could just be a normative fact that some fact has this motivational force for a rational agent. So the nature of normative force does not tell us where that force comes from.

\section{Gridlock}

\subsection{Three Dominant Types of View about Practical Reasons}

While the questions of the content of a practical reason, the nature of normative force, and the source of a reason's normativity are logically independent, there are plausible substantive relationships among their answers. Combinatorially speaking, there are 27 possible groupings of the three leading answers to each question, not all of which make happy bedfellows. Interestingly, philosophers have been overwhelmingly attracted to three particular combinations. I will call them Type 1, Type 2, and Type 3 views. 


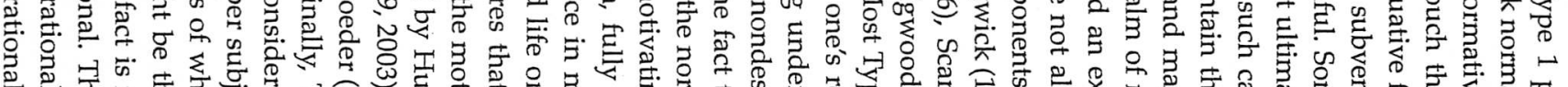

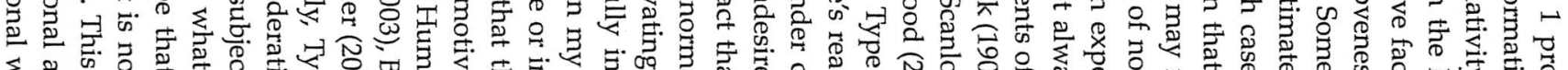

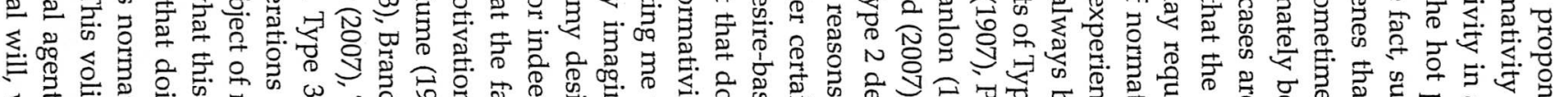

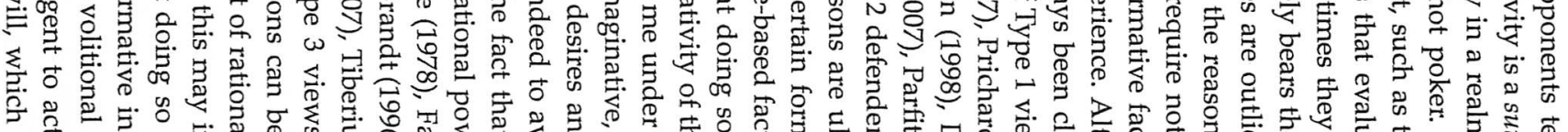

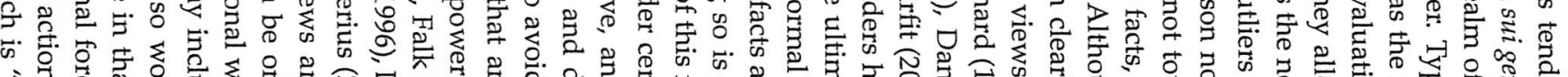

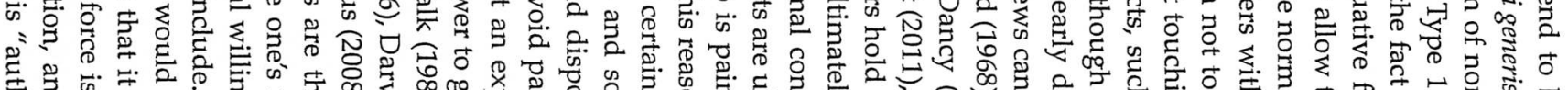

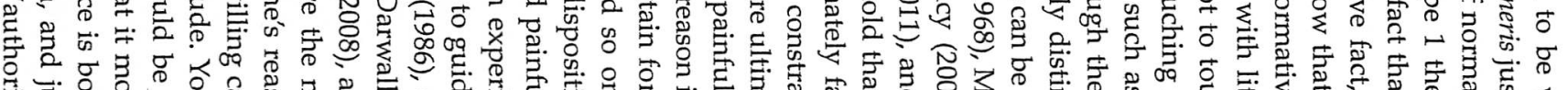

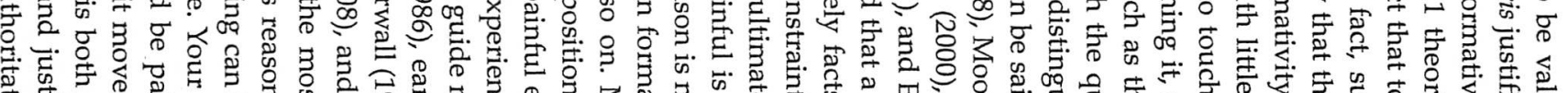

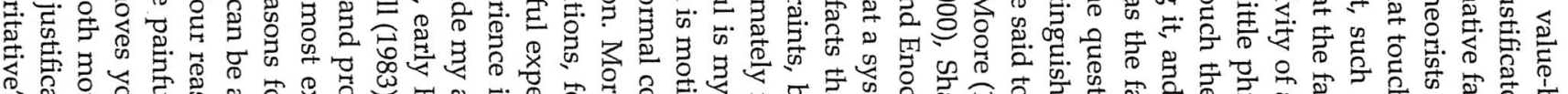

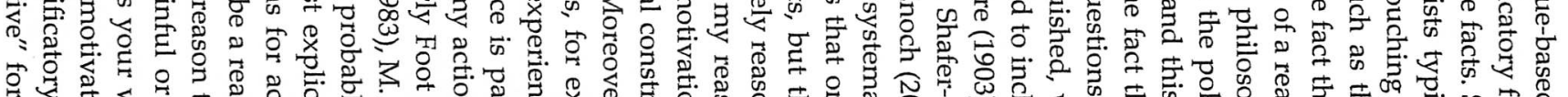

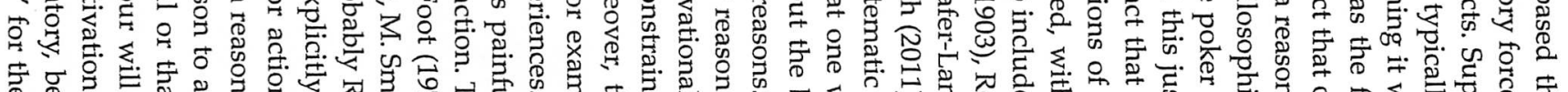

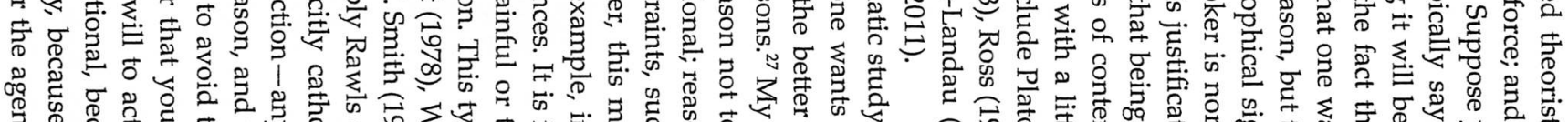

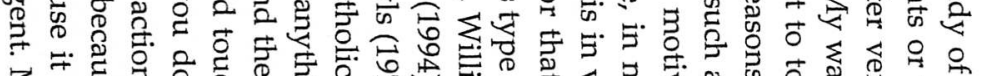

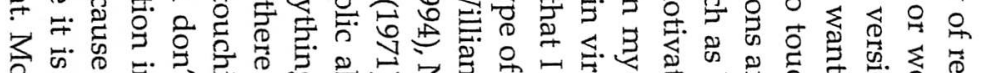

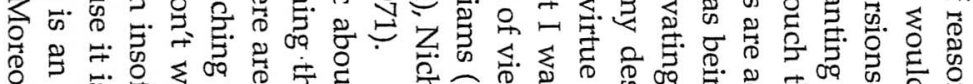

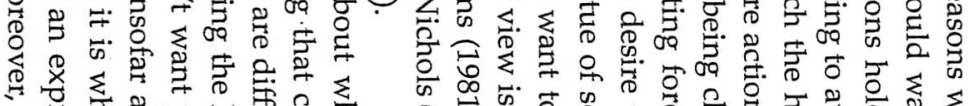

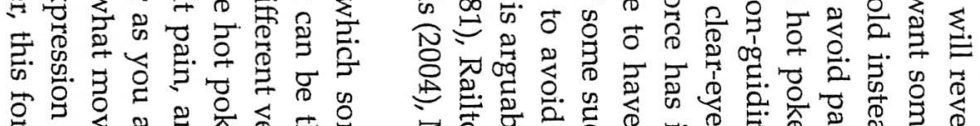

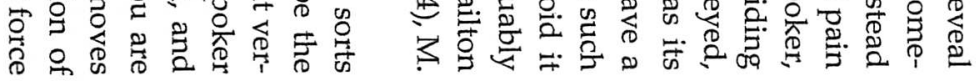

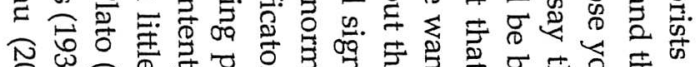

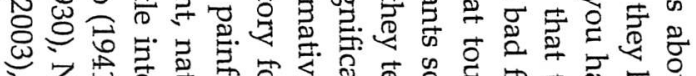

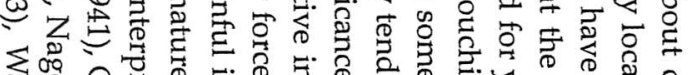

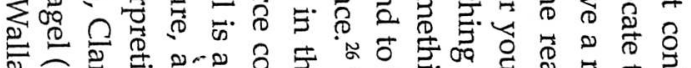

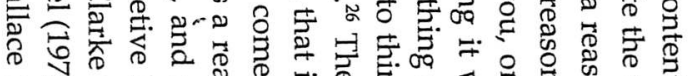

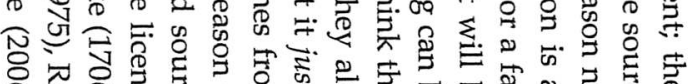

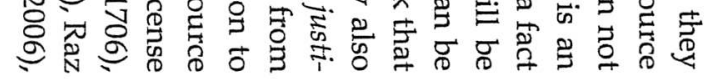

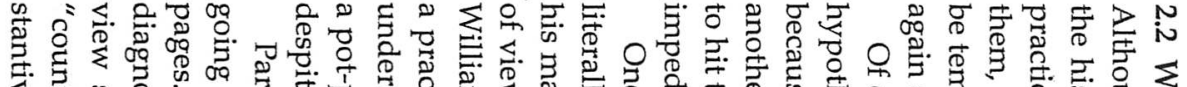

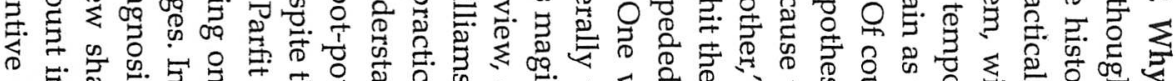

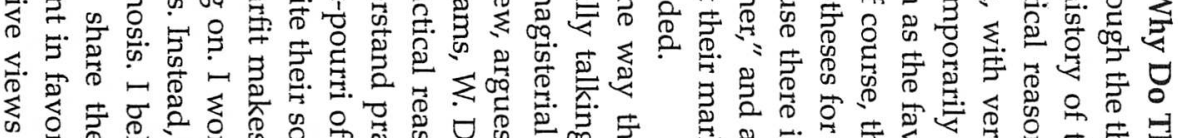

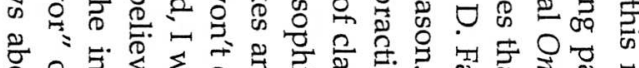

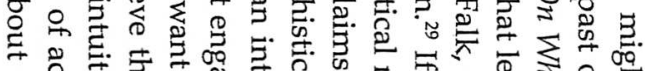

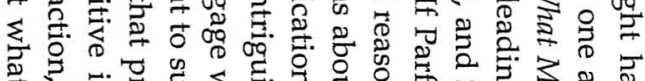

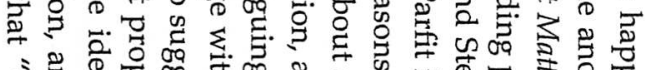

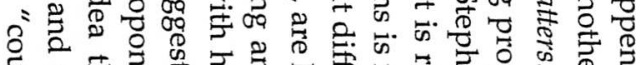

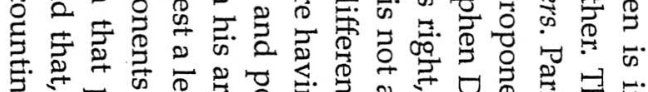

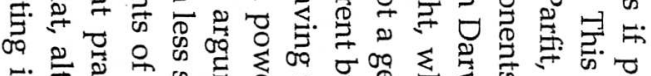
5.

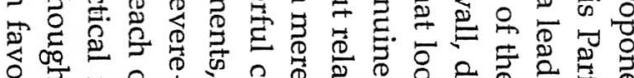

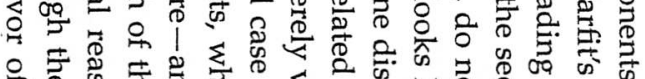

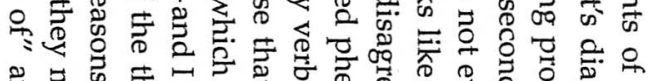

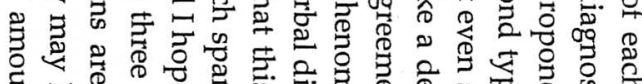

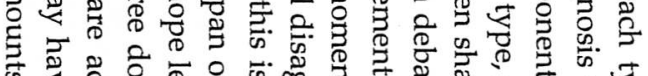
के

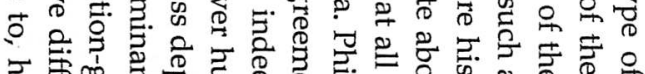

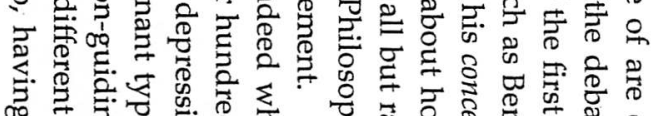

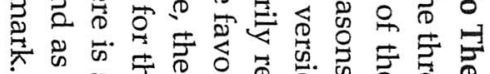

(1) क क

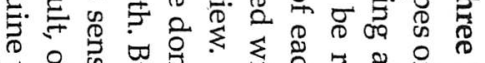

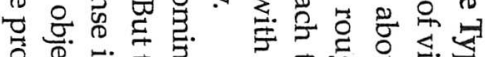

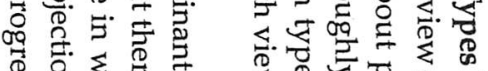

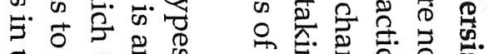

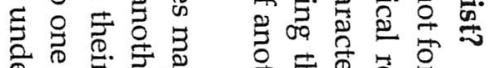

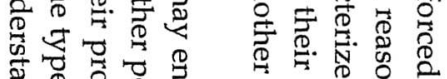

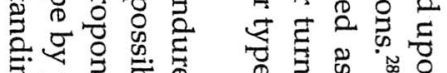

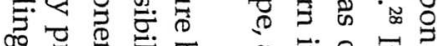

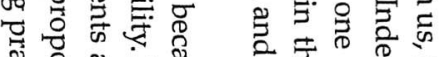

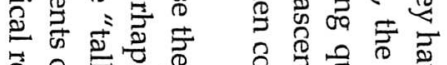
范。它要

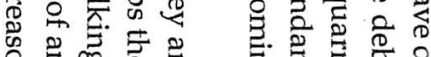

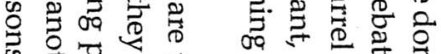

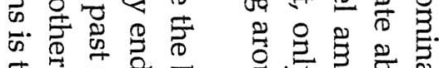

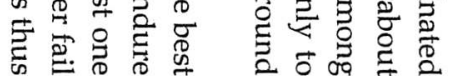

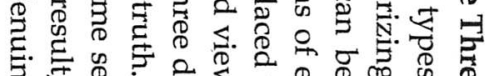

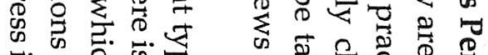

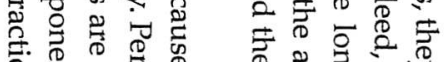

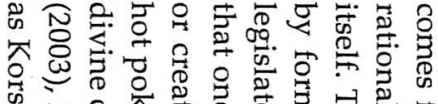
o

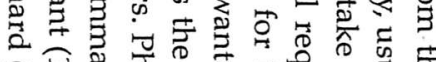

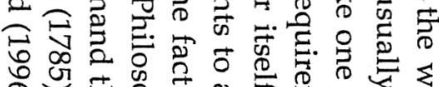

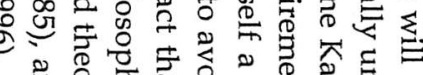

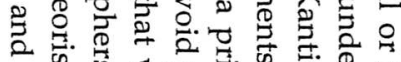

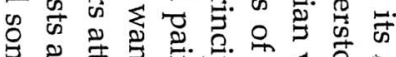

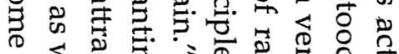

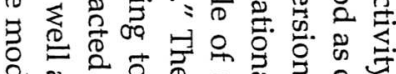
\%

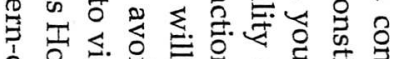

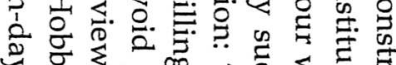

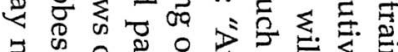

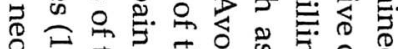

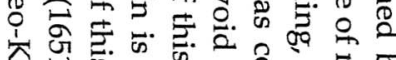

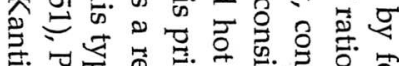

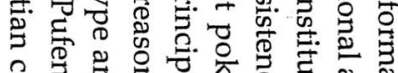

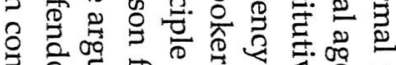

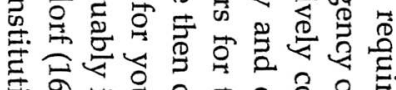

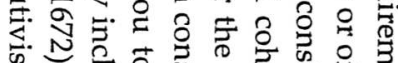
它 N

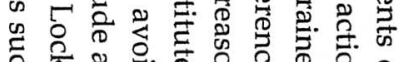

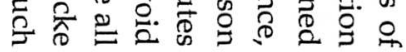


thin, intuitive notion is sufficient for them to share the concept of a practical reason. If this is right, the question then becomes whether there is nevertheless some explanation as to why, despite this shared concept, theorists often seem to be talking past one another.

\subsection{Argumentative Cocoons}

We can start with the conjecture that proponents of each type of view seem to take as a starting point within our framework a certain assumption about the nature of normative force, and note that once this assumption is in place, the rest of their view naturally follows. These starting points themselves may derive from prior commitments to naturalism or nonnaturalism about reality.

The Type 1 theorists, for example, seem to anchor their thinking about practical reasons in the substantive assumption that normativity is a sui generis, justificatory force. From this assumption, it's quite natural for them to go on to hold that this force has its source in normative facts and that the content of reasons is given by facts about the value or worth of things or the nonevaluative facts that subvene them. From an assumption that normative force is justificatory, a tidy Type 1 package easily follows.

If, instead, normativity is thought to be a motivating force, then it's natural to think that this force has its source in our desires and dispositions, for what could be the source of a motivation other than some other (actual or counterfactual) motivations? And since one is being naturalistic about both the nature of normativity and its source, one might as well be naturalistic about content too and maintain that the ultimate bearers of normativity are natural facts. The genesis of Type 2 views I suspect has this form; defenders start with substantive assumptions about what normative force could plausibly be-it has to be natural - and from there, the rest of their view naturally unfolds.

Finally, it seems plausible that, given larger metaphysical commitments, Type 3 theorists start off wedded to the idea that normative force is essentially something that grips the will. (They have this view because they doubt the capacity of desires and normative facts to explain why anything is authoritative for the agent). Once you think that normativity is a volitional force, then it is natural for you to think that its source is in (rational) willing and that the content of a practical reason can be anything that can be the subject of (rational) willing. Indeed, a Kantian-type package seems almost to fall out of the assumption that normative force is volitional force.

These starting points are not benign. They create an argumentative gridlock among the three types of view because the arguments for each view derive their force largely from their respective substantive assumptions about the nature of normative force, while the leading arguments against each view derive their force largely from opposing assumptions about normative force. Thus opponents of one type of view present arguments that presuppose something about the nature of normative force that the strongest arguments for the target view presuppose to be incorrect. In this way, the objections to each type of view fail to hit their mark. By lacking a common substantive view about the nature of normative force, the arguments in the debate fail to engage with what lies at the heart of the disagreement between them-the nature of normative force.

Consider, for instance, what proponents of the first type of view regard as a compelling, and perhaps decisive, objection against views of the second type:

According to Type 2 views, someone with a certain array of desires may have reason to want agony, understood as an intensely disliked sensation, for its own sake. But this is clearly false; no one has reason to want agony for its own sake, whatever his desires.

This is the nub of Parfit's famous "Agony Argument," and it has its roots in the idea that there are goods whose value doesn't depend on what one wants or would want under evaluatively neutral conditions. ${ }^{30}$ Any view that has as a consequence that someone can in principle have a reason to want agony for its own sake must be rejected. Those sympathetic to the idea that normative force is a sui generis justificatory force-that action-guiding force is not itself motivating force-will likely find this argument, especially as Parfit so nicely lays it out, decisive against Type 2 views.

But many proponents of the second type of view find the argument largely untroubling. If the person in question has an intrinsic desire to have agony for its own sake, and if having the desire-or the agony - in no way frustrates or diminishes the satisfaction of any of his other desires or the desires he would have under certain formal constraints, then, yes, indeed, he has a reason to want agony for its own sake. That's exactly as it should be. The agony argument makes no real dent because, for proponents of Type 2 views, normativity - "counting in favor of" - is assumed to be a matter of motivation, and how can someone have a reason-and thus be motivated-not to have a desire if he could not, given certain formal constraints, be motivated not to have such a desire? ${ }^{31}$

Investigation of the argumentative structure of this exchange reveals that Parfit's objection is not really aimed at Type 2 views tout court but more specifically at the view of normative force that it assumes to be the case. But since proponents of the second type are, commonly, in the grip of a substantive assumption about what normative force is like, the argument fails to hit its mark. This is not a flaw in the argument but a feature of the argumentative 
structure of the debate. By taking a firm substantive stand on the nature of normative force - it must be a motivating force-the intuitive force of objections from the point of view of a different substantive stand - it is a sui generis justificatory force-fails to have argumentative power.

Suppose we modify Parfit's objection so that it includes as an explicit premise that normativity is a matter of motivating force-what Parfit's opponents assume to be the case. It would then go something like this:

Suppose, as a substantive hypothesis, that normativity is a matter of motivational force under certain formal constraints. It's possible that someone non-instrumentally wants agony for its own sake under these formal constraints. Since desires are motivating, it follows that this desire could have normative force. ${ }^{32}$

So far, this is only an observation about the upshots of a possible psychology under a substantive assumption about normative force, but not yet an objection.

In order to turn the observation into an objection, a further claim is needed, namely, that the assumption that normativity is a matter of motivation is mistaken. This claim might, in turn, be supported by another: "Abstracting from any substantive assumptions about the nature of normative force, a noninstrumental desire for agony for its own sake does not have normative force." This is essentially an appeal to purported intuitions about what could have normative force, apart from any substantive assumptions about what normative force might be like. But now we can see that the Parfitian objection is not against the second type of view about practical reasons tout court but more particularly against its answer to the question of the nature of normative force. We might reformulate the nub of Parfit's Agony Argument like this:

Type 2 views make a mistake when they assume that normativity is a motivating force because intuitively, according to the thin, inituitive idea of "counting in favor of," a non-instrumental desire for agony for its own sake does not have normative force, which it could have if normativity were a motivating force.

With the target of Parfit's argument more clearly in view, however, we can see why there is an impasse. Proponents of the second type claim not to have the intuition that it is odd to say that the noninstrumental desire for agony for its own sake is not "normative" in the neutral sense, that is, that it doesn't count in favor in the thin, intuitive sense upon which all interlocutors to the debate can agree. As they see things, the best account of normativity in the neutral sense is as a motivating force. This is not to say they define normativity in these terms; rather their substantive views about normativity make it hard for them to feel the intuitive pull of Parfit's example.

In short, for Parfit's objection to hit its target, it must be supposed that normativity is not simply a matter of what one would be motivated to do under suitable formal constraints. This is because the force of the objection is sup posed to be that we intuitively think that someone does not have a reason even though he/she is motivated under these constraints. But the force of the objection presupposes a substantive view of the nature of normativity that is not shared by the view against which it is leveled.

Having belabored discussion of this first example, we can move more quickly through others since the core problem is the same. Consider the leading objection that proponents of Type 3 views have made against proponents of Type 1 views:

According to Type 1 views, someone can have a reason to do something even though this reason in no way engages his will. But this is absurd; reasons have to "get a grip" on those for whom they are reasons in order for them to be reasons for that person.

This is more or less Korsgaard's famous argument against normative realists, and it has its roots in the idea that nothing can be a reason for someone unless it can engage his rational agency, where "rational" here means not substantive rationality but what Scanlon has called "structural" rationality, the rationality of requirements. ${ }^{33}$ Those sympathetic to the idea that normative force is a force that moves the will, tend to find this argument, properly spelled out, compelling.

But proponents of Type 1 views find the enthusiasm with which the objection is lodged against them somewhat baffling. Why should one think that a sui generis justificatory force must engage the will of the agent? Insofar as reasons get a grip on agents, they do so when such agents are rational-in the substantive sense, that is, recognizing and responding to those reasons. Asking why something's being a reason should have a grip on a rational agent hardly makes sense. What it is to be rational in this sense is to be gripped by one's reasons. The objection seems to presuppose that normativity must be some kind of volitional or motivational force, but since it isn't, the argument misses its mark

The same goes for other familiar arguments against the first type of view: the metaphysical and epistemological worries that Mackie made familiar. Those arguments get their punch from the assumption that normativity must be a natural force-what else, could it be and how else could we come to know what has it? If, however, we remain neutral on the nature of normative 
force, resting content with the thought that, natural or not, normativity is not more queer than other sorts of necessity we can't do without, we pull their punch.

Finally, consider the leading objection made by proponents of the first and second types of view to a version of the third:

According to certain versions of Type 3 views, having a reason to $x$ is nothing more than willing a principle of $x$-ing in accord with the requirements of practical rationality. But the question, arises, "Why follow the requirements of practical rationality?" And the answer given by proponents of the third view has to be either, "it's good to follow the requirements of practical reason," in which case the third view appeals to something with normativity that goes being willing a principle in accord with the requirements of practical reason - the "goodness" of following such requirements-, or "there's a requirement of practical reason that one follow the requirements of practical reason," in which case the question arises all over again, and we are led to an infinite regress of requirements of practical reason. The third view cannot successfully answer the question, "What reason do we have to will in accordance with the requirements of practical rationality?"

This "regress argument," among other objections, has led the bulk of philosophers, most of whom endorse some version of Type 1 or Type 2 views, to dismiss the third as a nonstarter. ${ }^{34}$ But to proponents of Type 3 views, this objection is simply misguided. If normativity is a sui generis volitional force deriving from the rational will, then there can be constitutive requirements governing the proper exercise of the will which can make something a reason. By hypothesis, something doesn't count as a rational willing or, indeed, as nondefective action at all, unless it conforms to the requirements of practical reason; that's part of what it is to be rational willing or a nondefective action. Thus, since having a reason just is willing or nondefectively acting in accord with rational requirements, asking what reason one has to will in accord with rational requirements is a nonsensical question. Once one takes as given that normativity is just volitional force-and more specifically - that something's having this volitional force is a matter of one's willing according to the rational law, the regress objection doesn't seem to get started..$^{35}$

Our purpose is not to engage in substantive debate about the three dominant types of view but only to give some examples of how the argumentative force of some of the leading objections to each are hostage to assumptions about the nature of normative force, assumptions not shared by their target views. We have seen how, because of unshared assumptions about normative force, these objections fail to hit their mark.

\subsection{Argumentative Gridlock}

Much of philosophical debate proceeds as follows. Everyone shares the concept-for example; "knowledge" - at issue. Views about knowledge, then, are about a common matter of inquiry. Proponents of theory A of the concept will offer a strong criticism of theory B. Proponents of theory B will do their best to undermine or answer this criticism, sometimes by clarifying, deepening, or modifying their view, and will endeavor to show that their theory, despite its difficulties, has greater theoretical merit overall than that of their rivals. Proponents of theory A will do the same. There is no argumentative gridlock but genuine back-and forth engagement over issues with resulting modifications to existing views.

The debate about practical reasons has a different structure. By hypothesis, philosophers share the concept of a normative practical reason-it is a consideration that "counts in favor" of performing a certain action or having a certain attitude. In fashioning theories of practical reasons, however, they take a substantive position on the nature of normative force and from this the rest of their view - on content and source-naturally unfolds. But as we have seen, this move from an assumption about the nature of normative force to a full view about practical reasons is problematic in that it creates an argumentative cocoon around the view to which it naturally gives rise. Proponents of one type cannot effectively criticize opponents of another since their criticisms presuppose a view about the nature of normative force rejected by their opponents. This is so even though they share the concept of a practical reason as something that "counts in favor" of an action or attitude.

Now one way out of this gridlock would be to recognize that what is essentially at issue in the debate between the three types of view is the nature of normative force. But there's the rub. We have no idea how to make progress on the question of the nature of normative force. The nature of normative force is plausibly one of those "hardest" problems, like the nature of substance or consciousness, about which it may be best to make certain assumptions in an attempt to move forward in understanding other matters. It is thus unsurprising that philosophers have helped themselves to assumptions about the nature of "counting in favor of" in developing theories of practical reasons. Taking the plunge on a hard problem in order to see where it leads is often a good strategy for tackling a philosophical problem. But, as I have suggested in the case of understanding practical reasons, substantive assumptions about normative force are far from benign; they have had the effect of imposing a structure on the debate that leads to argumentative gridlock.

This argumentative situation bears some similarity to an impasse in the debate about abortion. When a pro-choicer appeals to the absolute right, ceteris paribus, of a woman to determine what happens to her own body in arguing against prohibitions to second-trimester abortion in cases of rape, a pro-lifer 
might fail to see that this reason has absolute strength not because he defines or conceptually fiats a second-trimester fetus as a person but because he has a substantive metaphysical view about what such a fetus is that precludes him from seeing how there could be an absolute right of another to destroy it. In both cases, we have substantive metaphysical views standing in the way of appreciating what are supposed to be claims that favor one substantive view over another. And in both cases we are genuinely stymied over how to make progress on that metaphysical question.

As is common in many philosophical debates, deep metaphysical questions can infect other debates in which they strictly have no proper place. For example, sometimes first-order normative theorizing is infected with assumptions about whether everything is natural or whether there are nonnatural facts or properties. Theories about what makes something morally good, for instance, should not be driven by assumptions about whether everything is natural-so that whatever makes things morally good must be natural. Instead, normative theorizing should be neutral on this deep metaphysical question and instead be attuned to the subtleties of higher level facts that might be relevant to determining what makes something morally good as a substantive, normative matter. Something similar may be at work in the present debate. Deep metaphysical assumptions about the nature of what there could be-everything is at bottom natural, for instance-may underwrite substantive assumptions about the nature of normativity that in turn wreak havoc in debate about the metaphysics of practical reasons.

\section{Coda: A Focus on Source?}

If the state of inquiry into practical reasons is as I have described it, the question then arises, What now? We can again turn to our framework for a possible answer.

If my diagnosis of the gridlock is correct, and if I'm right that we are presently ill-equipped to make progress on the nature of normative force, we might try a different tack. To break the stranglehold of the three dominant types of view, we might abstract away from assumptions about the nature of normative force-and, more generally, stop allowing the metaphysical question of what there ultimately could be infect higher level debates-and focus instead on the other questions of our framework, the questions of the content of reasons and of their normative source. By focusing on these questions without already having in hand a substantive stand on the nature of normative force, we will naturally bring to bear different sorts of considerations in defending possible views. So, for instance, we might focus our attention on the nature of desires to see how they could be systematic bearers or grounds of normativity.$^{36}$ Or we might try to understand the will. The last extended book-length treatment of the will dates from over 30 years ago. ${ }^{37}$

I suggest that we focus on the question of source. The strategy of abstracting away from assumptions about normative force and focusing on normative source has not gained much traction so far, I believe, because the question of source is thought to be obscure. This chapter is one attempt to try to make it less so. The question, "What makes a consideration 'count in favor' in the thin intuitive sense we can all grasp?" is not one that need stymie us.

Whether thinking about normative source will help illuminate practical reasons remains to be seen. I want to end by describing one way in which a focus on source might naturally suggest a new and fruitful way of thinking about practical reasons.

Philosophers tend to assume that the way to individuate a reason is the same way to individuate a cause-by its "content." Since causality is univocal in its source, this is a good strategy for cause. But if we are to be neutral as the nature of normativity, we should be open to the possibility that there are multiple sources of normativity, a possibility so far (to my knowledge) ignorned in the debate about practical reasons. ${ }^{38}$ If there can be multiple sources of normativity, then a plausible way to individuate reasons will be by their content and source. The same "content" - a single fact or consideration-can be the content of two quite different reasons if what makes that consideration actionguiding is different in each case. The same point can be put less dramatically by emphasizing that there are two different ways in which something can be a reason-via normative fact and via one's desires. We need not talk about having two different reasons with the same content but rather a reason with a specific content, which may be a reason in one of two ways.

Take, for example, the fact that an experience is painful. This fact may be action-guiding in virtue of the normative fact that being painful is a reason to avoid things with that feature. What makes the fact of being painful normative is some normative fact. Thus this fact-with this normative source-is a reason not to touch the hot poker. But perhaps the fact that an experience is painful can also be action-guiding in virtue of one's intrinsic desire to avoid pain. Your intrinsic desire to avoid pain might make the fact that it's painful action-guiding. In this way, the very same content-that it's painful-can be two different practical reasons. ${ }^{39}$ Or, again, more concessively, being painful can be a reason in one of two ways.

Notice that this result-that those who have an intrinsic desire to avoid pain for its own sake have more reason to avoid it that those lacking such a desire-accounts for our intuition that, even if everyone has a reason to avoid pain for its own sake, regardless of her desires to have or not to have such disliked sensations, someone with an intrinsic desire to avoid pain for its own sake would seem to have more reason than someone without such a desire. ${ }^{40}$ 


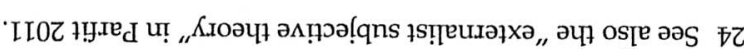

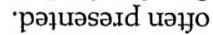

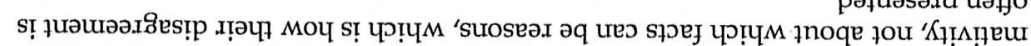

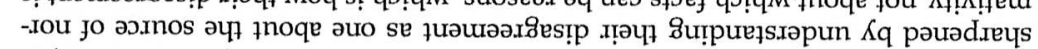

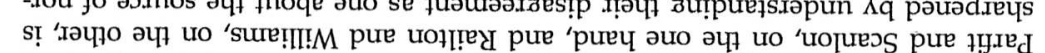

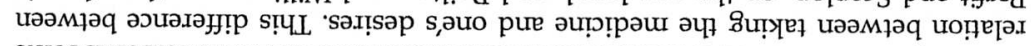

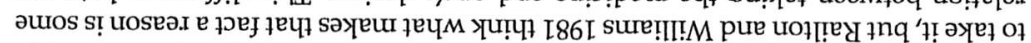

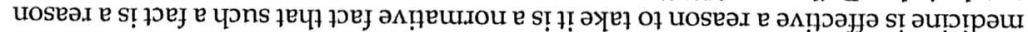

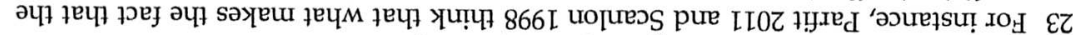

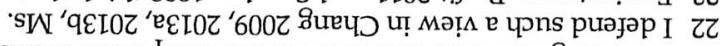

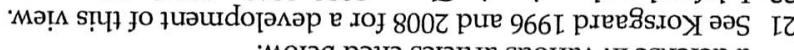

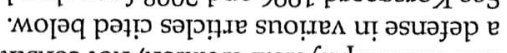

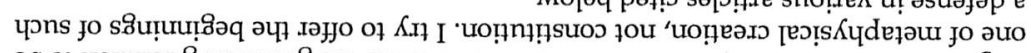

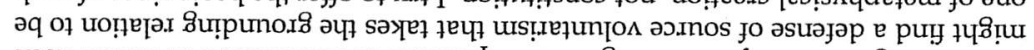

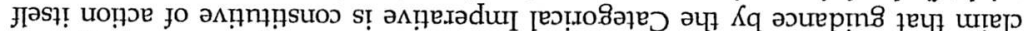

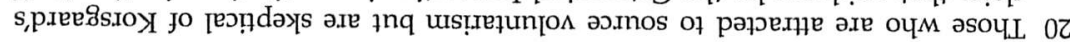
8002 ‘966L p.reesis.to

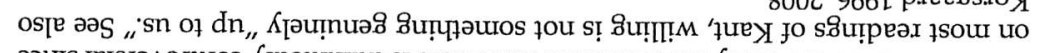
әวu!̣s [е!

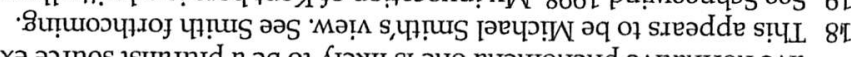

7 '

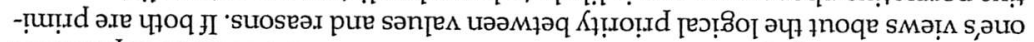

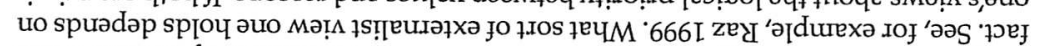

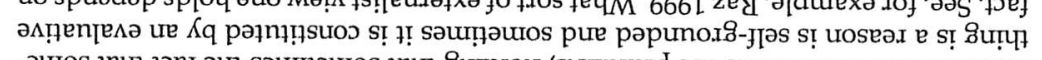

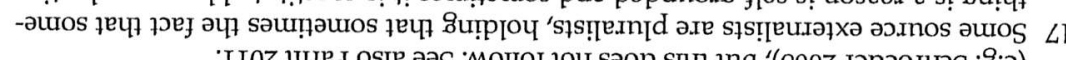

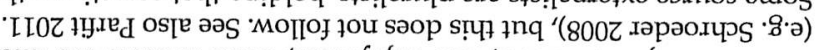

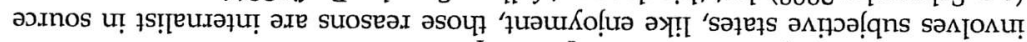

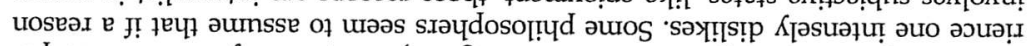

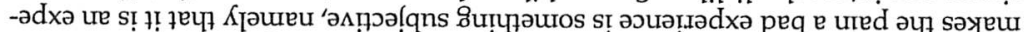

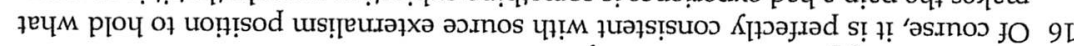
K!̣

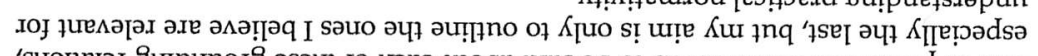

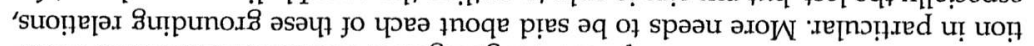

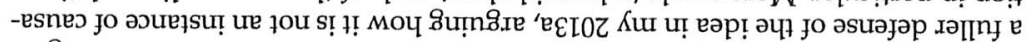

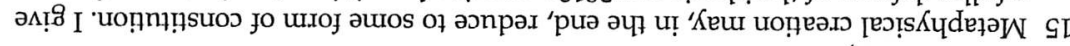

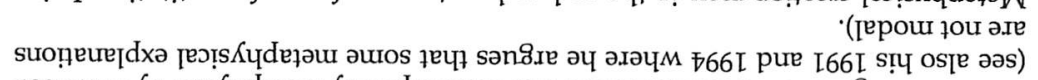

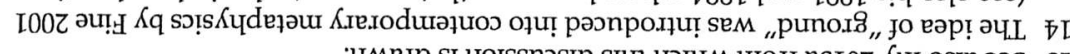

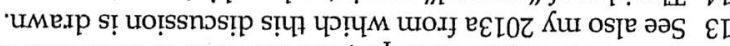

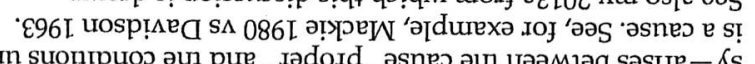

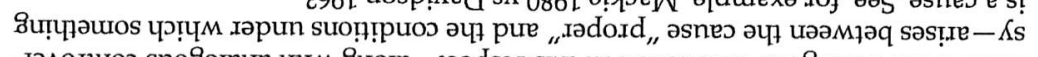

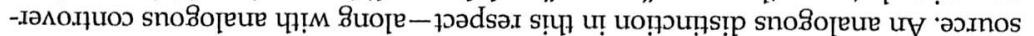

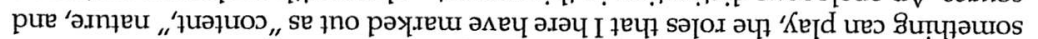

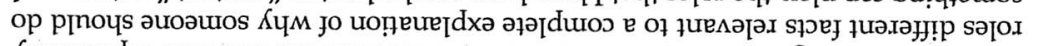

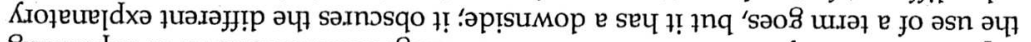

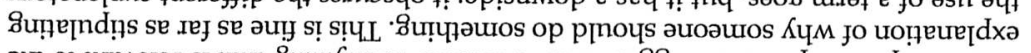

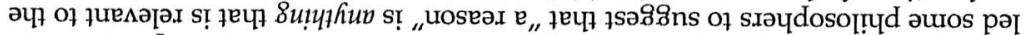

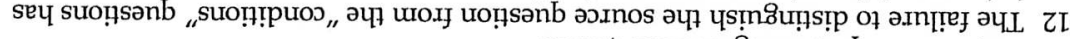

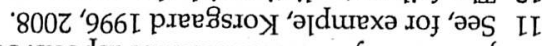

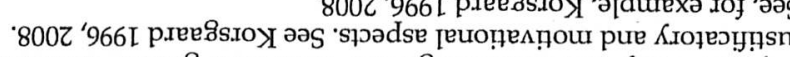

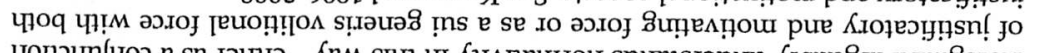

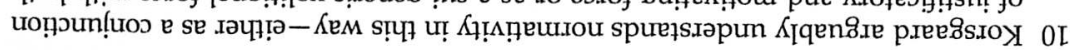

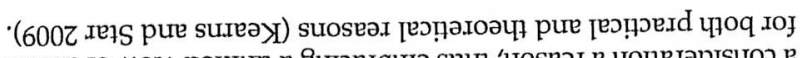

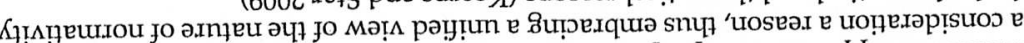

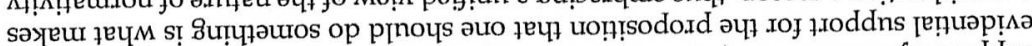

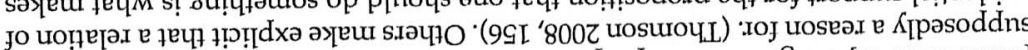
S! uoseat

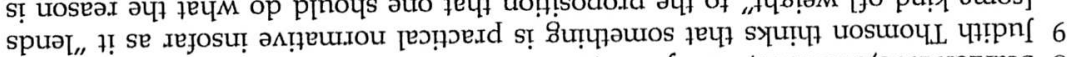
. (8uturosutiof) әuие

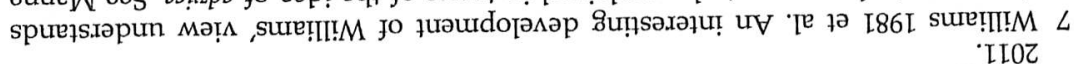

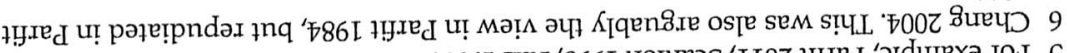

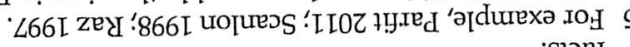
stove

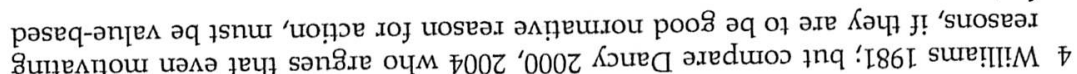

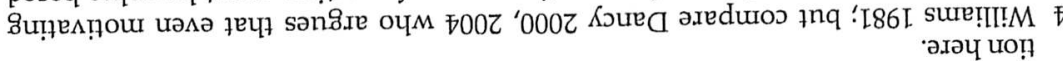

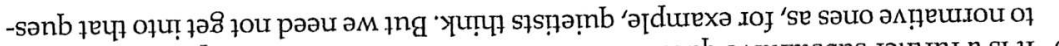

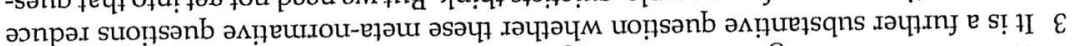

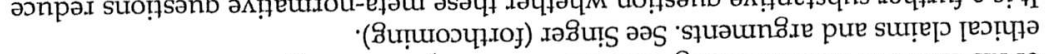

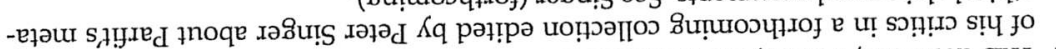

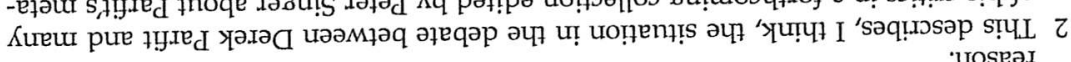
"uosea. [E 'K

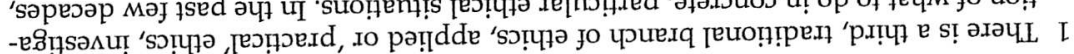

Səฺ̣ON

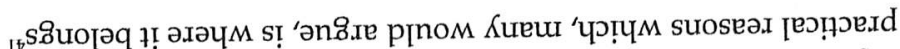

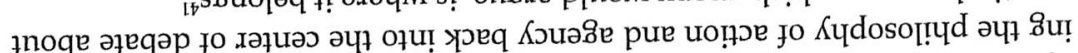

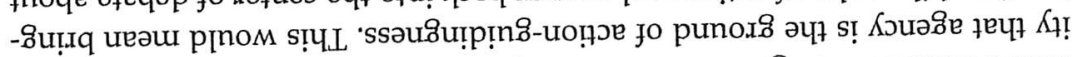

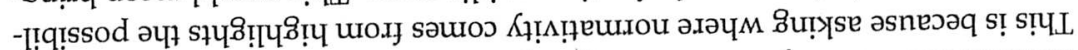

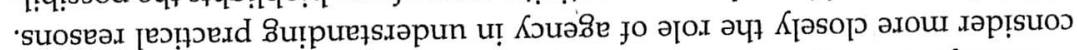

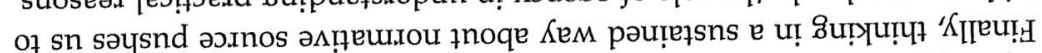

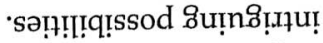

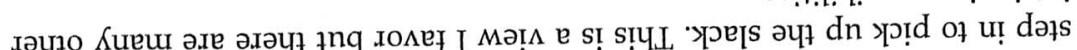

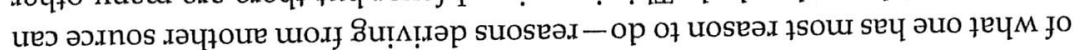
uoțsənb әцұ хәмsue of Кәе

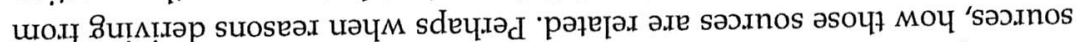

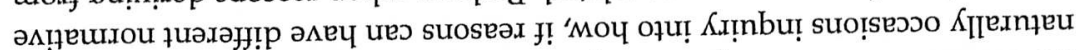

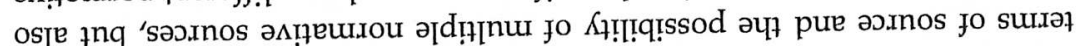

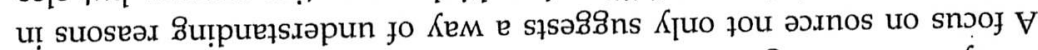

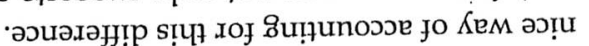

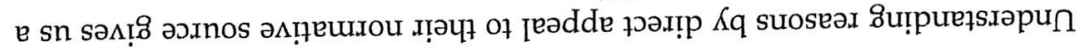


25 This is one of the main points I attempt to make in Chang 2004.

26 See for example Scanlon 1998, ch. 1; Parfit 2011, 52-6; Raz 1997. These exceptions are discussed in Chang 2004.

27 Most Type 2 theorists elide the question of what makes some fact a reason with the question of what is the reason, but once this distinction is made, perhaps most the question of what is the reason, but once this distinction is made, perhaps most
would allow, as Type 1 theorists do, that nondesire-based facts can or must be ultimate reasons.

28 This is not to say that every view about practical reasons is a version of one of the three dominant views. Some neo-Kantians, for example, have views that $\mathrm{cu}$ across the dominant views, and are in particular, externalists about source. Thoma Hill 1991, 2002 thinks that there is a normative fact-being rational is acting on such-and-such consideration - that is that in virtue of which the consideration is a reason. Other neo-Kantians are externalist about source in other ways, grounding normativity in the intrinsic value of the good will (Herman 1993) or of the person herself (Anderson 1993). Julia Markovitz has recently suggested a view according to which the source of normativity is in our desires (or some relation to them) but normativity is a sui generis justificatory force (Markovitz forthcoming). Other theoJustifich ries not falling neatly into any of the types of view include expressivism, which is primarily a theory of normative judgments, and error theories, which might be understood as "negative" theories-for instance, as the negation of some of the claims of Type 1 views.

29 Parfit 2011.

30 This is Parfit's 'second' agony argument, but since I believe it is stronger than the 'first', I discuss only this one.

31 I believe this is the central thought behind Williams' declaration that he cannot understand how there could be 'external' reasons, reasons to do things that one could not, through sound deliberation, come to be motivated to do (William 1981).

32 The requirement that the desire be noninstrumental blocks evil demon cases in which the evil demon will torture you unless you desire agony for its own sake.

33 Scanlon 1998; Broome 2004.

34 See Railton 2004, Scanlon 2003, and relatedly Enoch 2006.

35 See especially Korsgaard 2009 who argues that since action is inescapable, and it must as a constitutive matter be guided by the rational law, it makes no sense to ask what reason we have to follow the rational law. But this constitutivist maneuver does not it seems to me, succeed. It can be constitutive of torture that pain be applied in an excrutiating way, and there can be creatures that for whom torture is nonoptional. This does not block the question, What reason is there to apply pain in nonoptional. This does not block the question, What reason is there
an excrutiating way? I discuss this objection further in my 2013a.

36 I interpret recent work by Peter Railton as developing this line of thought. Type 2 theorists, it seems to me, could make the most progress by taking this Railtonian approach. The crucial issue then becomes whether Type 2 theorists can get us the robust kind of normativity that Type 1 theorists (and common sense) suggests there is.

37 I am thinking of O'Shaughnessy's two-volume set from 1980.

38 I seem to be the only philosopher, to my knowledge, who has taken this possibility seriously. It would be nice to have some company. See my 2009, 2013a, 2013b, Ms.

39 An imperfect but suggestive analogy from physics: a single object, like a magnet, can exert more than one kind of force on an object-it can be an electromagnetic force and it can be a gravitational one. In a roughly analogous way, a single fact can be two kinds of reason, where the "kind" is not marked by the kind of normative be two kinds of reason, where the "kind" is not marked by the kind
force but rather by that in virtue of which the fact has normative force.
40 Of course, value-based opponents would say that this fact is explained by the fact that for those who have the desire to avoid pain the experience would be worse and it's being worse (or the ways in which it is worse) is the reason. I try to counter such an argument in my 2004 work.

41 Thanks to Kit Fine and Derek Parfit for helpful comments and to the editors of this volume for helpful editorial advice.

\section{Bibliography}

Anderson, E., 1993. Value in Ethics and Economics. Cambridge, MA: Harvard University Press.

Brandt, R., 1996. Facts, Values, and Morality. Cambridge: CUP.

Broome, J., 2004. "Reasons." In R. J. Wallace, P. Pettit, S. Scheffler, and M. Smith, eds, 2004.

Chang, R., Ms. "Do We Have Normative Powers?" Draft.

-, 2013b. "Commitment, Reasons, and the Will." Oxford Studies in Metaethics, 8, pp. 74-113.

-, 2013a. "Grounding Practical Normativity: Going Hybrid." Philosophical Studies, 164 (1), pp. 163-87.

-, 2009. "Voluntarist Reasons and the Sources of Normativity." In D. Sobel and S. Wall, eds, Practical Reason and Action. Cambridge: CUP, pp. 243-71.

-, 2004. "Can Desires Provide Reasons for Action?" In R. J. Wallace, P. Pettit, S. Scheffler, and M. Smith, eds, Reasons and Values: Themes from Joseph Raz. Oxford: OUP.

Clarke, S., 1706. Discourse Concerning the Unchangeable Obligations of Natural Religion, and the Truth and Certainty of the Christian Revelation. In D. D. Raphael, ed., 1991, pp. 191-225.

Dancy, J., 2004. Ethics without Principles. Oxford: Clarendon.

,- 2000. Practical Reality. Oxford: OUP.

Darwall, S., 1983. Impartial Reason. Ithaca: Cornell University Press.

Davidson, D., 1963. "Actions, Reasons, Causes." Essays on Actions and Events. Oxford: Clarendon.

Enoch, D., 2011. Taking Morality Seriously: A Defense of Robust Realism. Oxford: OUP.

-, 2006. "Agency, Shmagency: Why Normativity Won't Come from What is Constitutive of Agency." Philosophical Review, 115, pp. 169-98.

Falk, W. D., 1986. Ought, Reasons, and Morality: The Collected Papers of W. D. Falk. Ed. W. D. Falk and K. Baier. Ithaca: Cornell University Press.

Fine, K., 2001. "The Question of Realism." Philosophers' Imprint, 1 (1), pp. 1-30.

-, 1994. "Essence and Modality." Philosophical Perspectives, 8, pp. 1-16.

-, 1991. "The Study of Ontology." Nous, 25 (3), pp. 263-94.

Foot, P., 1978. "Morality as a System of Hypothetical Imperatives." Reprinted in her Virtues and Vices. Oxford: Basil Blackwell.

Herman, B., 1993. The Practice of Moral Judgment. Cambridge, MA: Harvard University Press.

Hill, T., 2002. Human Welfare and Moral Worth: Kantian Perspectives. Oxford: OUP.

-, 1991. Autonomy and Self-Respect. Cambridge: CUP. 
Hobbes, T., 1651/1988. Leviathan. New York: Prometheus Books.

Huemer, M, 2005. Ethical Intuitionism. New York: Palgrave MacMillan.

Hume, D. 1739/1978. A Treatise of Human Nature. Edited by L. A. Selby-Bigge and P. H. Nidditch. Oxford: OUP.

Kant, I. 1785/1959. Foundations of the Metaphysics of Morals. Translated by Beck, Indianapolis: Bobbs-Merrill C.

Kearns, S. and Star, D., 2009. "Reasons as Evidence." Oxford Studies in Metaethics, 4 , pp. $215-42$.

Korsgaard, C., 2009. Self-Constitution: Agency, Identity, and Integrity. Oxford: OUP.

-, 2008. The Constitution of Agency: Essays on Practical Reason and Moral Psychology. Oxford: OUP.

,- 1996 . The Sources of Normativity. Cambridge: CUP.

Locke, J., 1689/2003. Two Treatises of Government, and, A Letter Concerning Toleration. Edited by I. Shapiro. London: Yale University Press.

Mackie, J., 1980. The Cement of the Universe. Oxford: OUP.

- 1977. Ethics: Inventing Right and Wrong. Harmondsworth: Penguin Books.

Manne, K., Forthcoming. "Internalism about Reasons: Sad but True?" Philosophical Studies.

Markovits, J., Forthcoming. Moral Reasons. Oxford: OUP.

Moore, G. E., 1971. Principia Ethica. Cambridge: CUP.

Nagel, T., 1975. The Possibility of Altruism. Oxford: Clarendon.

Nichols, S., 2004. Sentimental Rules. Oxford: OUP.

Nozick, R., 1981. Philosophical Explanations. Cambridge, MA: Harvard University Press.

Parfit, D., 2011. On What Matters. Oxford: OUP

,- 1986 . Reasons and Persons. Oxford: OUP.

Plato, 1941. The Republic. Translated by B. Jowett. New York: The Modern Library.

Prichard, H. A. 1968. Moral Obligation and Duty and Interest: Essays and Lectures by H.A. Prichard. Edited by W. D. Ross and J. O. Urmson. Oxford: OUP.

Pufendorf, S. von, 1672. On the Law of Nature and of Nations as discussed in Schneewind 1998, pp. 88-9.

Railton, P., 2004. "How to Engage Reason: The Problem of Regress." In R. J. Wallace, P. Pettit, S. Scheffler, and M. Smith, eds 2004.

-, 2003. Facts, Values, and Norms: Essays Toward a Morality of Consequence. Cambridge: CUP, 2003.

_, 1989. "Naturalism and Prescriptivity." Social Philosophy and Policy, 7, pp. 151-71. Rawls, J., 1971. A Theory of Justice. Cambridge, MA: Belknap Press.

Raz, J., 1999. Engaging Reason: On the Theory of Value and Action. Oxford: OUP.

- 1997. "Incommensurability and Agency." In R. Chang, ed., 1997. Reprinted in Raz 1999, ch. 3.

-, 1986. The Morality of Freedom. Oxford: OUP.

Ross, W. D., 1930. The Right and the Good. Oxford: Clarendon.

Scanlon, T., 2003. "Metaphysics and Morals." Proceedings and Addresses of the American Philosophical Association, 77, pp. 7-22.

-, 1998. What We Owe to Each Other. Cambridge, MA: Belknap Press.

Schroeder, M., 2008. Slaves of the Passions. Oxford: OUP.

Schneewind, J., 1998. The Invention of Autonomy. New York: CUP.
Shafer-Landau, R., 2003. Moral Realism: A Defense. Oxford: Clarendon.

Sidgwick, H., 1907. The Methods of Ethics. 7th edn (1st edn 1874, reprinted 1981). Indianapolis: Hackett Publishing.

Singer, P., ed., Forthcoming. Does Anything Really Matter? Parfit on Objectivity. Oxford: OUP.

Smith, M., 2013. "Parfit's Mistaken Meta-ethics." In Singer, ed., forthcoming. -, 1994. The Moral Problem. Oxford: Blackwell Publishing.

Tiberius, V., 2008. The Reflective Life: Living Wisely with Our Limits. Oxford: OUP.

Thomson, J. J., 2008. Normativity. Chicago: Open Court.

Trogdon, K., Forthcoming. "An Introduction to Grounding." In M. Hoeltje, B. Schnieder, and A. Steinberg, eds, Dependence. Munich: Philosophia Verlag.

Velleman, D., 2000. The Possibility of Practical Reason. Oxford: Clarendon.

Wallace, R. J., 2006. Normativity and the Will. Oxford: OUP.

Wallace, R. J., Pettit, P., Scheffler, S., and Smith, M., eds, 2004. Reason and Value: Themes from the Moral Philosophy of Joseph Raz. Oxford: OUP.

Wedgwood, R., 2007. The Nature of Normativity. Oxford: OUP.

Williams, B., 1995. "Internal Reasons and the Obscurity of Blame." Making Sense of Humanity and Other Philosophical Papers, 1982-1993. Cambridge: CUP.

-, 1981. "Internal and External Reasons." Moral Luck. Cambridge: CUP. 